\author{
Tomasz Rachwal \\ Zakład Przedsiębiorczości i Gospodarki Przestrzennej \\ Instytut Geografii \\ Uniwersytet Pedagogiczny im. KEN w Krakowie
}

\title{
Ocena projektu zmian podstawy programowej podstaw przedsiębiorczości (przedstawionej przez MEN w 2008 r. w ramach reformy systemu edukacji)
}

Współczesne tendencje rozwoju cywilizacyjnego, prowadzące do kształtowania się społeczeństwa informacyjnego oraz związanej z nim gospodarki opartej na wiedzy, wymagają stałej modernizacji procesu dydaktycznego na wszystkim poziomach edukacyjnych. Szczególnie istotne wydaje się to w warunkach polskich, gdzie wciąż jeszcze trwające procesy transformacji gospodarczej, zachodzące w warunkach nasilających się procesów globalizacji gospodarki światowej i integracji europejskiej, oraz wyzwania związane $z$ przechodzeniem od fazy industrialnej i postindustrialnej do fazy informacyjnej rozwoju cywilizacyjnego powodują konieczność odpowiedniego przygotowania nowych kadr pracowników i całego społeczeństwa do funkcjonowania w coraz bardziej złożonych systemach społecznych, gospodarczych i kulturowych. Przygotowanie to odbywa się m.in. poprzez kształtowanie postaw przedsiębiorczych na wszystkich etapach rozwoju człowieka, od etapu wczesnoszkolnego po uczelnię wyższą, a także w okresie aktywności zawodowej.

W odpowiedzi na tę współczesną potrzebę kształtowania postaw przedsiębiorczych i edukacji ekonomicznej społeczeństwa, w Zakładzie Przedsiębiorczości i Gospodarki Przestrzennej Instytutu Geografii Uniwersytetu Pedagogicznego im. KEN w Krakowie, w 2004 r. podjęto organizację nowego cyklu metodycznych konferencji naukowych z udziałem instytucji edukacyjnych, biznesowych, doradców metodycznych i nauczycieli, głównie przedsiębiorczości, geografii i przedmiotów ekonomicznych. Pierwsza konferencja z tego cyklu była poświęcona przedsiębiorczości w kontekście współczesnych wyzwań cywilizacyjnych (2004), kolejne zaś: roli przedsiębiorczości w podnoszeniu konkurencyjności społeczeństwa i gospodarki (2005), aktywizacji gospodarczej (2006), gospodarce opartej na wiedzy (2007) oraz kształtowaniu społeczeństwa informacyjnego (2008). Celem tego cyklu konferencji jest prezentacja wyników prac badawczych i wymiana doświadczeń związanych z problematyką przedsiębiorczości, w szczególności nt. funkcjonowania gospodarki rynkowej, procesów gospodarczych w Polsce, w Europie i na świecie, finansów państwa i jednostek samorządu terytorialnego, funkcjonowania przedsiębiorstw (w tym zakładania własnej firmy), rynku kapitałowego, systemu bankowego, podatkowego i ubezpieczeń, zachowań na rynku pracy oraz postaw przedsiębiorczych człowieka i jego umiejętności interpersonalnych. Silny nacisk kładzie się na aspekty przestrzenne rozwoju przedsiębiorczości, w szczególności w układach lokalnych i regionalnych Polski na tle innych krajów europejskich. Specjalne sesje poświęcone są zagadnieniom etycznym w przedsiębiorczości. Zgodnie z przyjętą formułą i jej metodycznym charakterem, drugi dzień każdej z konferencji (od 2008 r. funkcjonujący jako obrady Ogólnopolskiego Zjazdu Nauczycieli 
Przedsiębiorczości) jest poświęcony wymianie wiedzy i doświadczeń na temat metodyki nauczania przedsiębiorczości i innych przedmiotów ekonomicznych na wszystkich poziomach edukacji, konfrontacji poglądów pracowników szkół wyższych, doradców metodycznych i nauczycieli na temat celów, treści i metod nauczania przedsiębiorczości. Obrady zmierzają do odpowiedzi na pytanie, w jakim stopniu zasoby wiedzy naukowej z zakresu przedsiębiorczości powinny być przekazywane na wszystkich etapach edukacji szkolnej, od szkoły podstawowej do kształcenia na poziomie akademickim. W obradach każdej konferencji przewidziana jest dyskusja specjalna o problemach edukacji w zakresie przedsiębiorczości na różnych poziomach edukacji (w tym nt. kształtu aktualnie obowiązującej podstawy programowej i projektów jej zmian), w której udział biorą nauczyciele i doradcy metodyczni, dzielący się swoimi przemyśleniami opartymi na bogatym doświadczeniu w pracy $\mathrm{z}$ uczniami w różnego typu szkołach. Rolę współorganizatora i patrona merytorycznego konferencji, obok Fundacji „Edukacja dla Społeczeństwa" i Wydawnictwa Nowa Era, przyjęła także od 2007 r. Komisja Nadzoru Finansowego w ramach realizacji swoich statutowych celów w zakresie edukacji ekonomicznej społeczeństwa, związanej z funkcjonowaniem rynków finansowych. W organizacji tego cyklu oraz kilkudziesięciu innych, odbywających się od 2002 r. w całej Polsce jedno- i dwudniowych konferencji dla doradców metodycznych i nauczycieli przedsiębiorczości, brały udział także inne znaczące instytucje społeczne, gospodarcze i edukacyjne. W efekcie w ciągu kilku lat ukształtowała się ogólnopolska platforma rzetelnej dyskusji nt. edukacji w zakresie przedsiębiorczości pomiędzy sferami nauki, biznesu i praktyki szkolnej. Z dużym uznaniem należy ocenić działania różnego typu instytucji edukacyjnych dążących do systematycznego doskonalenia celów, treści i metod kształcenia w zakresie przedsiębiorczości. Wyrazem tego typu działań jest także kolejna już propozycja zmiany podstawy programowej, przygotowana przez $\mathrm{MEN}^{1}$, poddana analizie w niniejszej pracy. Projekt pt. Doskonalenie podstawy programowej wychowania przedszkolnego oraz kształcenia ogólnego w poszczególnych typach szkół pod kątem jej zgodności z wymogami gospodarki opartej na wiedzy został opracowany przy dofinansowaniu ze środków Europejskiego Funduszu Społecznego w ramach priorytetu III Programu Operacyjnego Kapitał Ludzki.

W wyniku analizy przedstawionej w październiku 2008 r. wersji projektu nowej podstawy programowej podstaw przedsiębiorczości ${ }^{2}$ nasuwają się pewne sugestie dotyczące założeń ogólnych, układu treści (w tym ,rozłożenia” treści pomiędzy III - gimnazjalny i IV - ponadgimnazjalny etap edukacyjny) oraz szczegółowych zapisów treści kształcenia i osiągnięć uczniów. Już wstępna analiza projektu wskazuje, że chociaż jest on milowym krokiem naprzód $\mathrm{w}$ porównaniu $\mathrm{z}$ dotychczas obowiązującą podstawą programową i poprzednimi projektami zmian, to jednak w niewielkim stopniu nawiązuje do współczesnej literatury przedmiotu w zakresie metodyki nauczania podstaw przedsiębiorczości, która jest już bardzo bogata i obejmuje wiele znaczących pozycji, mimo stosunkowo krótkiego okresu od wprowadzenia tego przedmiotu do kształcenia ogólnego, obowiązującego wszystkich uczniów. Należy uznać, że tylko w jednej serii wydawniczej: „Przedsiębiorczość-Edukacja” (Zioło, Rachwał, red., 2005, 2006, 2007, 2008), poświęconej problemom edukacyjnym w kształceniu przedsiębiorczości, opublikowano szereg prac, których wykorzystanie przy projektowaniu

\footnotetext{
${ }^{1}$ Poprzednia propozycja, przygotowana i przedstawiona w 2006 r. przez Instytut Spraw Publicznych na zlecenie MEN, została poddana analizie przez zespół Zakładu Przedsiębiorczości i Gospodarki Przestrzennej IG UP i zaprezentowana we wcześniejszej pracy (Górz, Rachwał 2006).

${ }^{2}$ Projekt został wdrożony do realizacji stosownym rozporządzeniem Ministra Edukacji Narodowej w grudniu $2008 \mathrm{r}$.
} 
nowej podstawy programowej wydaje się nie tylko korzystne, ale wręcz niezbędne. Prace te - opierając się na badaniach naukowych i analizie opinii praktyków życia szkolnego oraz uczniów - często rozstrzygają dylematy, z jakimi nadal borykają się, co wyraźnie widoczne jest w projekcie, twórcy reformy i autorzy podstawy programowej ${ }^{3}$. Są to m.in. prace dotyczące:

- kształtowania postaw przedsiębiorczych uczniów (Gabała 2005, Rachwał 2005), w tym w szczególności gimnazjalistów (Błażejewski 2006) i młodzieży wiejskiej (Milewska 2006) oraz postrzegania przez uczniów takich postaw (Kosała, Pichur 2008);

- nauczania i realizacji przedmiotu podstawy przedsiębiorczości w szkołach ponadgimnazjalnych (Makieła M., Makieła B. 2005; Juchnowicz 2005), w tym opinii uczniów i rodziców o przedmiocie (Osuch E., Osuch W. 2005) oraz jego rangi w edukacji szkolnej i miejsca w wykształceniu ogólnym (Kawecki 2005, Tracz 2006);

- kryteriów doboru treści nauczania do podstawy programowej i programu nauczania z podstaw przedsiębiorczości (Tracz 2005) oraz metod nauczania (Łazowska 2005, Sowislok 2008, Tracz, Rachwał 2008), w tym wykorzystania multimediów (Śrutowska 2006, Kulikowska, Krasnodębska 2007, Soczówka 2007) i wybranych projektów edukacyjnych (Kulikowska, Krasnodębska 2006, Szmulczyńska 2006, Osuch E., Osuch W. 2007, Mrożek 2008, Szubert 2008);

- realizacji konkretnych treści programowych i propozycji scenariuszy lekcji: z zakresu edukacji europejskiej (Piróg 2005, Desperak, Depczyńska 2007), rynku pracy i bezrobocia (Baran 2005, Batorska 2005, Mitura, Jamroz 2005), sektora bankowego (Nowak 2005), globalizacji i korporacji transnarodowych (Kilar 2007), obsługi klienta (Rachwał M., Rachwał T. 2005), ochrony konsumenta (Szczepańska 2005), komunikacji interpersonalnej (Makieła B. 2006) i etyki biznesu (Nowak 2008);

- matury z podstaw przedsiębiorczości (Bartoń 2005, Tracz, Rachwał 2007) i projektu podstawy programowej kształcenia ogólnego w zakresie rozszerzonym z podstaw przedsiębiorczości, umożliwiającej wprowadzenie tego przedmiotu do kanonu przedmiotów maturalnych (Rachwał, Kudełko, Tracz, Wach, Kilar 2008);

- przygotowania nauczycieli do nauczania przedsiębiorczości (Zioło 2005, Borowiec 2005, Tracz, Rachwał 2007).

Oprócz wymienionej serii, na uwagę zasługują pozycje dotyczące edukacji w zakresie przedsiębiorczości w szkołach wyższych pod red. J. Targalskiego (1994, 1995, 2003) oraz wiele poradników metodycznych wydawanych w ramach pakietów do nauczania przedsiębiorczości w szkołach ponadgimnazjalnych (np. Bielecka 2005, Maj 2003, Makieła, Rachwał 2008, Mikina, Sienna 2002, Musiałkiewicz 2006, Wawrzyniak, Szymczykiewicz, Namysł 2006).

\footnotetext{
${ }^{3}$ Przykładem takiego dylematu jest kwestia matury z podstaw przedsiębiorczości, której rzekomo nie da się wprowadzić do polskiego systemu edukacji ze względu na unikatowy charakter przedmiotu (położenie nacisku na kształtowanie postaw i wyposażanie uczniów w umiejętności, a nie w wiedzę, miałoby uniemożliwiać opracowanie arkusza maturalnego) oraz rzekome nieprzygotowanie nauczycieli do prowadzenia tego przedmiotu w zakresie rozszerzonym. Dyskusja ta, prowadzona od kilku lat w różnego typu gremiach, w tym na forum ogólnopolskich konferencji z udziałem przedstawicieli nauki, oświaty i biznesu, została jednoznacznie rozstrzygnięta na płaszczyźnie „merytorycznej” (choć nie bez pojawienia się argumentów przeciwnych) na korzyść wprowadzenia podstaw przedsiębiorczości do kanonu przedmiotów maturalnych do wyboru, obok m.in. wiedzy o społeczeństwie, historii muzyki i historii sztuki, czego niestety zdają się nie zauważać twórcy reformy programowej i autorzy podstawy. Inicjatywa ta ma jednocześnie jednoznaczne poparcie wielu środowisk opiniotwórczych, w tym Konferencji Rektorów Uczelni Ekonomicznych oraz znacznej liczby nauczycieli, których podpisy z poparciem dla tego rozwiązania były wielokrotnie składane w MEN.
} 
Należy jednocześnie zauważyć, że kwestia reformy programowej edukacji ekonomicznej i przygotowania młodzieży do życia zawodowego w nowych realiach gospodarczych nie jest przedmiotem szczególnego zainteresowania tylko w Polsce i w innych państwach Europy Środkowej i Wschodniej transformujących swoje systemy gospodarcze. Jak wskazuje raport nt. kształtowania w ramach szkolnictwa obowiązkowego w poszczególnych systemach edukacyjnych krajów Europy tzw. kompetencji kluczowych (Kompetencje..., 2005), w obliczu takich zjawisk, jak rozszerzanie się Unii Europejskiej, starzenie się społeczeństw, nasilające się fale migracji, coraz bardziej skomplikowane ścieżki kariery zawodowej, stale utrzymujące się stosunkowo wysokie wskaźniki bezrobocia w wielu krajach i związane z tym ryzyko społecznego wykluczenia, w poszczególnych państwach Europy, w także tzw. „starych” członkach UE-15, zaczęto się baczniej przyglądać tym umiejętnościom i kompetencjom, których już wkrótce młody człowiek będzie najbardziej potrzebował w życiu dorosłym. W krajach europejskich w coraz większym stopniu obserwuje się dążenie do określenia zakresu tych wiadomości, umiejętności, kompetencji, zdolności i postaw, które pozwolą obywatelom na czynne uczestnictwo w tworzącym się właśnie społeczeństwie wiedzy. Próby ustalenia tych podstawowych atrybutów efektywnego funkcjonowania w życiu politycznym, gospodarczym, społecznym i kulturalnym podejmowane są zarówno na szczeblu narodowym, jak i międzynarodowym. W centrum zainteresowania osób inicjujących te próby znajdują się relacje między edukacją szkolną a gospodarką. Efektywność edukacji szkolnej w zakresie przygotowywania młodych ludzi do integracji ekonomicznej i społecznej jest bowiem coraz częściej i coraz powszechniej kwestionowana (Kompetencje..., 2005). Jak powszechnie wiadomo, w wyniku wieloletnich prac badawczych i długiej dyskusji na forach różnych instytucji UE (głównie grupy roboczej ds. umiejętności podstawowych Komisji Europejskiej), w europejskim obszarze edukacyjnym za jedną z ośmiu kluczowych kompetencji uznano właśnie przedsiębiorczość, obok m.in. komunikowania się w języku ojczystym i obcym, kompetencji w zakresie matematyki czy technologii informacyjnych i komunikacyjnych (Zalecenie..., 2006). W efekcie w wielu krajach Europy rozpoczęto prace nad zreformowaniem systemów edukacji w taki sposób, aby sprzyjały kształtowaniu kompetencji związanych z przedsiębiorczością. Podobnie jak w Polsce, na różnych płaszczyznach prowadzone są więc prace badawcze i dyskusje na temat celów, treści i metod kształcenia w zakresie przedsiębiorczości. Przykładami takich płaszczyzn wymiany myśli są m.in. sieć ERENET (Entrepreneurship Research and Education Network of Central European Universities) oraz międzynarodowy projekt badawczy Fifobi - fit for bussiness: Developing business competencies in school, którego realizacja przewidziana jest na lata 2009-2011. Stawia to jednak przed polską reformą programową szczególnie wysokie wymagania związane z presją konkurencyjną wynikającą z unowocześniania treści nauczania i systemów edukacyjnych w innych krajach. Państwa te także dostrzegły konieczność zwiększenia efektywności kształcenia w zakresie przedsiębiorczości, chociaż, w porównaniu z Polską, bardzo często była ona już na bardzo wysokim poziomie. Wynika z tego konieczność wprowadzenia wyjątkowo odważnych, dobrze przemyślanych i na najwyższym poziomie merytorycznym zmian programowych $\mathrm{w}$ zakresie edukacji ekonomicznej, uwzględniających współczesne i przyszłe, prognozowane uwarunkowania rozwoju cywilizacyjnego. W przeciwnym razie państwa znajdujące się już i tak na wyższym niż Polska poziomie rozwoju społeczno-gospodarczego, będą - dzięki doskonalszemu kształtowaniu w społeczeństwie tej kompetencji kluczowej - rozwijać się jeszcze szybciej, co zwiększy dystans cywilizacyjny naszego kraju wobec tych krajów, zamiast go zgodnie z narodową strategią rozwoju zmniejszyć, oraz obniży pozycję konkurencyjną polskiej młodzieży na europejskim rynku pracy. 


\section{Uwagi do założeń ogólnych wprowadzenia reformy programowej i miejsca podstaw przedsiębiorczości w edukacji szkolnej}

W świetle obiegowej opinii, utwierdzanej przez wypowiedzi przedstawicieli MEN, okres wdrażania nowej podstawy programowej podstaw przedsiębiorczości jest bardzo odległy, gdyż nowa podstawa programowa dla szkół ponadgimnazjalnych będzie obowiązywać dopiero od roku szkolnego 2012/2013. I rzeczywiście, według projektu reformy programowej (Projekt..., 2008): „Podstawę programową kształcenia ogólnego dla szkół ponadgimnazjalnych, których ukończenie umożliwia przystąpienie do egzaminu maturalnego, określoną w załączniku nr 4 do niniejszego rozporządzenia, stosuje się: 1) począwszy od roku szkolnego 2012/2013 w klasach I liceów ogólnokształcących, liceów profilowanych i techników; (...). Podstawę programową kształcenia ogólnego dla zasadniczych szkół zawodowych (...) stosuje się, począwszy od roku szkolnego 2012/2013 w klasach I zasadniczych szkół zawodowych. (...)". Jednak w świetle analizowanej, wdrożonej przez MEN propozycji, edukacja w zakresie przedsiębiorczości rozpoczyna się już w gimnazjum, chociaż ma się to odbywać nie w ramach przedmiotu podstawy przedsiębiorczości, ale wiedzy o społeczeństwie (co jest niezbyt fortunnym rozwiązaniem, o czym szerzej w dalszej części tej pracy), a więc zmiany programowe w tym zakresie weszłyby w życie już od roku szkolnego 2010/2011 lub nawet 2009/2010 (jeśli lekcje WOS byłyby realizowane w I klasie). Wynika to wprost z cytowanego już projektu (Projekt..., 2008): „Podstawę programową kształcenia ogólnego dla gimnazjów (...) stosuje się począwszy od roku szkolnego 2009/2010 w klasach I gimnazjum”. Wydaje się, że przy tak poważnej reformie programowej i wielu istotnych zmianach w systemie edukacji oraz szczegółowych treściach kształcenia, wskazany byłby dłuższy okres na przygotowanie się szkół i nauczycieli do tych przekształceń, tym bardziej, że wiele zapisów w podstawie programowej wydaje się niejasnych i z różnych względów kontrowersyjnych. Należy się więc zgodzić z wieloma opiniami środowisk naukowych i oświatowych, że przy tak ambitnych zamierzeniach i tylu wątpliwościach, jakie wzbudza projektowana reforma, jej wejście w życie należałoby odsunąć w czasie.

Niewątpliwą zaletą projektowanych zmian jest zmiana układu podstawy programowej, w której dotychczas obowiązujące „cele edukacyjne”, „zadania szkoły”, „treści nauczania” i „osiągnięcia” zostały zastąpione przez określenie „,celów kształcenia - wymagań ogólnych” oraz ,treści nauczania i umiejętności - wymagań szczegółowych”, choć można mieć zastrzeżenia do niezbyt zręcznego sformułowania „treści nauczania i umiejętności”4. W uzasadnieniu projektu zmian (Uzasadnienie..., 2008) czytamy, że „regulacja treści kształcenia w języku efektów kształcenia poprzez określenie wymagań na koniec każdego etapu edukacyjnego ma na celu precyzyjne określenie tego, czego szkoła zobowiązana jest nauczyć przeciętnego ucznia. Przeniesienie uwagi na efekty kształcenia, dokonujące się aktualnie w wielu krajach Europy, będzie szło w parze ze zwiększeniem autonomii szkoły w zakresie kształtowania procesu kształcenia. Sformułowanie podstawy programowej kształcenia ogólnego w języku wymagań (główne kierunki oraz cele kształcenia w danej dziedzinie sformułowane są w języku wymagań ogólnych, a treści nauczania oraz oczekiwane umiejętności - w języku wymagań szczegółowych) stanowi także pierwszy krok do wypełnienia zaleceń Parlamentu Europejskiego i Rady z 23 kwietnia 2008 r. w sprawie ustanowienia europejskich ram

\footnotetext{
${ }^{4}$ Nauczanie obejmuje przecież wyposażanie uczniów zarówno w wiedzę, jak i w umiejętności. Poza tym wydaje się, że lepszym określeniem byłyby „treści kształcenia”, bo przecież autorom chodzi zapewne o efekty procesów nauczania i uczenia się. Trudno przecież założyć, że cele te są osiągane tylko w procesie nauczania.
} 
kwalifikacji dla uczenia się przez całe życie (Dz.Urz. UE C z 6.05.2008 r., str. 1). Takie podejście zasługuje na szczególną uwagę i pochwałę, szkoda jednak, że często jest ono tylko deklaratywne i czasem w szczegółowych zapisach trudno doszukać się precyzyjnych zapisów wymagań w ,języku efektów kształcenia”. Przykładowo, zapis jednego z celów kształcenia w gimnazjum brzmiący: „(...) [uczeń] przedstawia podmioty gospodarcze (gospodarstwa domowe, przedsiębiorstwa, państwo) i związki między nimi”, pozostawia wątpliwości, jak nauczyciel powinien rozumieć osiągnięcie tego efektu kształcenia określanego jako ,przedstawienie” podmiotów gospodarczych. Podobne wątpliwości budzą np. zapisy: „(...) [uczeń] wyjaśnia, jak się zakłada i prowadzi indywidualną działalność gospodarczą" (na czym miałoby polegać wyjaśnienie ,prowadzenia” działalności gospodarczej?) czy w szkole ponadgimnazjalnej: „(...) [uczeń] omawia transformację gospodarki Polski po 1989 r.” (czy jakikolwiek uczeń na poziomie tej szkoły jest w stanie „omówić” ten proces?).

W uzasadnieniu projektu zmian (Uzasadnienie..., 2008) znalazło się również wiele innych zapisów, które teoretycznie można by uznać za zmierzające w dobrym kierunku: „Oprócz korzyści płynących z precyzyjnego określenia wiadomości i umiejętności, które uczeń zdobywa na każdym etapie kształcenia w języku efektów kształcenia, celem projektu rozporządzenia jest także poprawa jakości kształcenia, osiągnięcie spójnego programowo procesu kształcenia, dostosowanego do możliwości i indywidualnych potrzeb uczniów oraz uwzględniającego zwiększone aspiracje edukacyjne uczniów i młodzieży.

Proponuje się złączenie programowe gimnazjum i szkoły ponadgimnazjalnej, którego celem jest unowocześnienie programu szkoły i uniknięcie dwukrotnej, pospiesznej realizacji tych samych treści programowych [podkreślenie T.R.]. Z dotychczasowych doświadczeń wynika bowiem, że okres 3 lat jest zbyt krótki, by pomieścić w nim pełny cykl kształcenia ogólnego i uzyskać satysfakcjonujące efekty kształcenia. (...). Klasa I szkoły ponadgimnazjalnej, w tym również zasadniczej szkoły zawodowej, będzie zamykała rozpoczęty w gimnazjum cykl kształcenia ogólnego, który zapewni solidne podstawy wykształcenia ogólnego. Począwszy od klasy II szkół ponadgimnazjalnych obowiązkowe będą: język polski, język/języki obce, matematyka, wychowanie fizyczne, przysposobienie obronne - edukacja dla bezpieczeństwa oraz wychowanie do życia w rodzinie. Pozostałe zajęcia uczniowie będą wybierać spośród przedmiotów maturalnych - dwa lub trzy przedmioty w zakresie istotnie rozszerzonym - pod kątem przygotowania do egzaminu maturalnego i studiów wyższych. Funkcję dopełniającą będą miały na tym etapie bloki przedmiotowe - historia i społeczeństwo oraz przyroda, które uczniowie będą wybierać jako uzupełnienie wybranego profilu kształcenia”.

W świetle przedstawionych zapisów uzasadnienia nasuwa się pytanie o miejsce edukacji w zakresie przedsiębiorczości w świetle projektu reformy. Należy jednoznacznie stwierdzić, że przedstawiona koncepcja nie przewiduje w profilach kształcenia w szkole ponadgimnazjalnej szczególnego miejsca dla edukacji w zakresie przedsiębiorczości (edukacji ekonomicznej). Autorzy projektu najwyraźniej uznali, że nauki społeczne (w tym ekonomiczne) nie zasługują na odrębne wydzielenie, jako np. trzeci profil kształcenia, lub potraktowanie ich specjalnie, jak to ma miejsce w przypadku wymienionych w uzasadnieniu: wychowania fizycznego, przysposobienia obronnego - edukacja dla bezpieczeństwa oraz wychowania do życia w rodzinie.

$\mathrm{Na}$ edukację w zakresie przedsiębiorczości nie ma także szczególnego miejsca na III etapie (gimnazjum), na którym treści z zakresu przedsiębiorczości zostały marginalnie (chociaż $\mathrm{z}$,monstrualnym” wręcz wymiarem zakładanych efektów kształcenia w stosunku do niewielkiej liczby godzin) włączone do wiedzy o społeczeństwie. Jak wykazują doświadczenia i badania sondażowe prowadzone wśród nauczycieli, w efekcie takiego podejścia treści z zakresu przedsiębiorczości w WOS są marginalizowane przez nauczycieli tego przedmiotu, którzy 
z reguły nie są odpowiednio przygotowani merytorycznie do realizacji treści związanych z przedsiębiorczością (tzn. nie ukończyli studiów podyplomowych z podstaw przedsiębiorczości, a studia przygotowujące do nauczania tego przedmiotu nie zawierają z reguły zagadnień ekonomicznych w odpowiednim wymiarze godzinowym). Poza tym nauczyciele WOS, ze względu na ograniczone możliwości czasowe realizacji treści programowych, skupiają się na zagadnieniach tradycyjnie uznawanych za będące w centrum zainteresowania wiedzy o społeczeństwie, uznając że problematyka edukacji ekonomicznej w ramach tego przedmiotu jest kwestią drugorzędną.

Takie podejście jest być może efektem specyficznego trybu konsultacji społecznych projektu. W zasadzie nie przewidziano konsultacji w sprawie zmian programowych z jakimkolwiek stowarzyszeniem zajmującym się sensu stricte edukacją ekonomiczną, chociaż na liście instytucji do konsultacji społecznych było blisko 100 różnego typu stowarzyszeń czy innych organizacji III sektora. Zdziwienie budzi brak na liście partnerów społecznych, np. Polskiego Towarzystwa Ekonomicznego, chociaż są inne towarzystwa tego typu. W konsultacjach społecznych marginalnie zostały potraktowane również uczelnie wyższe (w tym pedagogiczne, o wyjątkowym doświadczeniu w zakresie metodyki nauczania poszczególnych przedmiotów), w których pracuje wielu wybitnych dydaktyków przedmiotowych i funkcjonują doświadczone zespoły badawcze, zajmujące się m.in. doborem treści programowych i efektami kształcenia w ramach poszczególnych przedmiotów na różnych poziomach edukacji. Projekt zmian programowych poszczególnych przedmiotów powinien trafić do zaopiniowania w pierwszej kolejności przez tego typu zespoły. Już na etapie tworzenia założeń projektu nowej podstawy zakresie przedsiębiorczości powinien być on konsultowany z departamentami edukacji ważniejszych instytucji ekonomicznych w kraju, jak Komisja Nadzoru Finansowego czy Narodowy Bank Polski. Niewłaściwie działająca platforma internetowa do oceny projektu, która uniemożliwiła wielu nauczycielom i autorowi niniejszej pracy wypełnienie i skuteczne przesłanie formularza opinii o projekcie, dopełniła niewłaściwy obraz sposobu przeprowadzania konsultacji społecznych projektu. Kontrowersje wokół prac nad podstawą wynikały także z braku jawności zespołów tworzących nową podstawę programową i recenzentów projektu, co w wielu środowiskach budziło wątpliwości odnośnie do kryteriów doboru osób do prac nad podstawą. Choć zapewne dobierano osoby o wyjątkowym, uznanym autorytecie metodycznym i merytorycznym w danej dziedzinie, to trudno się nie zgodzić, że utajnienie ich nazwisk, zamiast pomóc, mogło tylko zaszkodzić promocji projektu i jego pozytywnemu odbiorowi zarówno w środowisku szkolnym, jak i w całym społeczeństwie. Wydaje się więc, że przy wprowadzaniu tego typu ambitnych zmian należałoby położyć większy nacisk na recenzowanie prac i konsultacje społeczne. Dobrym miejscem na tego typu konsultację są wspomniane wyżej metodyczne konferencje naukowe poświęcone przedsiębiorczości.

$\mathrm{Na}$ marginesie uwag o promocji projektu reformy programowej należy zauważyć, że już w samym jego tytule: „Doskonalenie podstawy programowej wychowania przedszkolnego oraz kształcenia ogólnego w poszczególnych typach szkół pod kątem jej zgodności z gospodarką opartą na wiedzy", podkreśla się szczególne uwarunkowania procesu zmian związane z budową GOW. Szkoda jednak, że ten termin - jak się wydaje kluczowy i „nośny” marketingowo - nie pojawia się z zapisach podstawy programowej nie tylko podstaw przedsiębiorczości, ale także żadnego innego przedmiotu (chociażby WOS). Skoro, ,zgodność” z GOW jest tak ważna, to czy $\mathrm{w}$ żadnym $\mathrm{z}$ wymagań stawianych uczniom nie powinno się pojawić to określenie współczesnej fazy rozwoju gospodarki? Jak można ich przygotować do życia i działania w warunkach budowy tego typu gospodarki, skoro nie zakładamy efektu kształcenia w postaci chociażby podstawowej znajomości warunków jej rozwoju? 
W założeniach reforma programowa ma wpływać także na rozwój kompetencji kluczowych. W uzasadnieniu czytamy: „(...) przewiduje się, że proponowane zmiany programowe przyczynią się do osiągnięcia celów określonych przez Komisję Europejską w Programie „Edukacja i Szkolenia 2010”, takich jak: rozwijanie kompetencji kluczowych (porozumiewanie się w języku ojczystym, porozumiewanie się w językach obcych, kompetencje matematyczne i podstawowe kompetencje naukowo-techniczne, kompetencje informatyczne, kompetencje społeczne i obywatelskie, umiejętność uczenia się, rozwiązywania problemów w twórczy sposób, inicjatywność i przedsiębiorczość [podkreślenie T.R.], świadomość i ekspresja kulturalna), co przyczyni się do osiągania lepszych wyników polskich uczniów w międzynarodowych badaniach OECD/PISA, zwiększenia odsetka osób z wykształceniem minimum średnim, lepszego przygotowania do studiów (...) oraz aktywności na rynku pracy" (Uzasadnienie..., 2008). Czy jednak autorzy zmian są w pełni świadomi „kluczowości” kompetencji, jaką jest przedsiębiorczość?

W uzasadnieniu projektu zmian pojawia się także zapis będący analizą wpływu projektowanych zmian na... przedsiębiorczość:

„Wpływ projektowanej regulacji na rynek pracy, konkurencyjność gospodarki i przedsiębiorczość, w tym funkcjonowanie przedsiębiorstw, oraz sytuację i rozwój regionalny.

Wejście w życie rozporządzenia będzie miało wpływ na lepsze przygotowanie absolwentów polskich szkół do kontynuowania nauki i funkcjonowania na rynku pracy. Pierwsi absolwenci szkół ponadgimnazjalnych wykształceni według nowych programów pojawią się na studiach, w szkołach policealnych lub na rynku pracy w roku 2015. Do tego czasu rozporządzenie nie będzie miało wpływu na rynek pracy, konkurencyjność gospodarki i przedsiębiorczość, w tym funkcjonowanie przedsiębiorstw, oraz sytuację i rozwój regionalny”.

Trudno nie zauważyć, że punkt ten został potraktowany zdawkowo, a przecież właśnie w przeciwieństwie do wielu innych aktów prawnych, które też muszą zawierać taki punkt oceny wpływu regulacji - to rozporządzenie może w istotny sposób wpłynąć na przedsiębiorczość czy konkurencyjność gospodarki. Twórcy reformy jakby nie zdawali sobie sprawy z ogromnego znaczenia systemu edukacji we współczesnych procesach rozwoju społeczno-gospodarczego fazy informacyjnej rozwoju i budowy gospodarki opartej na wiedzy.

Założony wymiar godzinowy kształcenia w zakresie przedsiębiorczości oraz brak możliwości realizacji tego przedmiotu na poziomie rozszerzonym wskazuje na to, że przedsiębiorczość, jako kompetencja kluczowa europejskiego obszaru edukacji, nie jest istotna z punktu widzenia nowych założeń programowych. W gimnazjum treści z zakresu przedsiębiorczości zostały umieszczone w przedmiocie wiedza o społeczeństwie (około 20 godz. z łącznie 60 godz. przeznaczonych na realizację całego przedmiotu, według zaleceń proponowane w II i III klasie), chociaż - jak wskazują dotychczasowe doświadczenia - treści te są marginalizowane przez nauczycieli WOS (jak już wspomniano, wynika to z braku odpowiedniego przygotowania do ich realizacji oraz graniczonej liczby godzin, co prowadzi do skupiania się na treściach podstawowych z zakresu kształcenia obywatelskiego). Takie podejście, co wielokrotnie podnoszono podczas konferencji poświęconych nauczaniu przedsiębiorczości, jest błędne, konieczne wydaje się więc wyodrębnienie tych treści w gimnazjum do osobnego przedmiotu podstawy przedsiębiorczości w ilości co najmniej 30 godz.

W szkole ponadgimnazjalnej kończącej się maturą przewidziano do realizacji 60 godz. ${ }^{5}$ podstaw przedsiębiorczości (w poradniku dla dyrektorów proponuje się realizację w II i III klasie) oraz 30 godz. przedmiotu fakultatywnego ekonomia w praktyce (jeśli uczeń go

\footnotetext{
${ }^{5}$ Należy zauważyć, że podane liczby godzin według stanu w październiku 2008 r. są orientacyjne, gdyż MEN nie zaprezentował rozporządzenia w sprawie ramowych planów nauczania (odnoszącego się do liczby godzin), podał tylko wymiar godzinowy nieoficjalne w poradniku dla dyrektorów szkół (Poradnik..., 2008).
} 
wybierze), a w zasadniczej szkole zawodowej - 60 godz. podstaw przedsiębiorczości, bez możliwości realizacji przedmiotu dodatkowego. Należy jednak zwrócić uwagę na to, że szanse na wybór przez uczniów przedmiotu ekonomia w praktyce i sensowną organizację zajęć są w praktyce minimalne, m.in. z powodu:

- braku oficjalnej propozycji MEN, w której klasie ten przedmiot powinien być realizowany, ale biorąc pod uwagę propozycję realizacji podstaw przedsiębiorczości w II i III klasie oraz następstwo treści, najodpowiedniejsza wydaje się klasa III (maturalna!), co spowoduje jego marginalne traktowanie wobec konieczności przygotowania się uczniów do matury;

- myląca nazwa przedmiotu (biorąc pod uwagę realizowane treści i podział nauk ekonomicznych) - dlaczego nie: przedsiębiorczość w praktyce?

- brak powiązania przedmiotu z egzaminem maturalnym - obniżona motywacja do wyboru, dodatkowo presja rodziców oraz nauczycieli na skupienie się na przedmiotach maturalnych. Zauważalna jest ponadto rażąca niekonsekwencja w zaprojektowaniu celów tego przedmiotu. Z jednej strony twórcy zakładają (Historia ..., 2008), że „przedmiot «Ekonomia w praktyce « ${ }^{6}$ stanowi zajęcia uzupełniające”, będące kontynuacją przedmiotu podstawy przedsiębiorczości, a $\mathrm{z}$ drugiej strony w następnym zdaniu stwierdza się, że „uczniów, którzy go wybiorą, wprowadza $\mathrm{w}$ realia funkcjonowania gospodarki, przygotowując ich do wejścia na rynek pracy". Czy jednak w ramach kształcenia ogólnego podstaw przedsiębiorczości wszyscy uczniowie nie powinni być wprowadzeni w realia gospodarki i przygotowani do wejścia na rynek pracy? Czy to przygotowanie ma objąć tylko uczniów wybierających ten nadobowiązkowy przedmiot? Należałoby te kwestię jednoznacznie rozstrzygnąć. Wydaje się, że problematyka rynku pracy jest absolutnie podstawowa i powinna być realizowana priorytetowo już w gimnazjum (a rozszerzana w szkole ponadgimnazjalnej) przez wszystkich uczniów, nie tylko wybranych. Należy przyznać, że jest to ciekawie zaprojektowany przedmiot, mający „na celu wykorzystanie wiedzy uczniów dotyczącej zagadnień ekonomicznych w praktycznych działaniach podejmowanych w szkole i poza szkołą". W materiałach informacyjnych czytamy jednak, że „uczniowie mogą prowadzić firmę uczniowską, brać udział w symulacyjnych grach ekonomicznych (również z wykorzystaniem technologii informatycznych), przeprowadzać analizę wybranego rynku lub podejmować inne projekty o charakterze ekonomicznym". Rodzi się wątpliwość, czy podczas realizacji pewnych gier symulacyjnych (np. szkolnej gry giełdowej) czy ,innych projektów ekonomicznych" zostanie zrealizowana podstawa programowa tego przedmiotu. Jest ona tak napisana, że w zasadzie realizacja założonych osiągnięć jest możliwa tylko poprzez realizację ,,przedsięwzięcia” uczniowskiego (firmy). Wydaje się więc konieczne zwiększenie swobody w realizacji tych treści. Wskazana byłaby np. możliwość wyboru przez nauczyciela problematyki związanej $\mathrm{z}$ edukacją finansową (ochrony klienta usług finansowych), tak ważna w obecnych czasach, szczególnie w okresie kryzysu na rynkach finansowych.

Nasuwa się więc pytanie: jaki jest cel wprowadzenia tego przedmiotu? Trudno się oprzeć wrażeniu, że jego pojawienie się jest przypadkowe. Sprawia on wrażenie „,zastępczego" rozszerzenia podstaw przedsiębiorczości, zamiast możliwości „normalnej” realizacji tego przedmiotu na poziomie rozszerzonym dla chętnych uczniów, jak w przypadku innych przedmiotów, np. WOS. Warto po raz kolejny podkreślić, że we współczesnych uwarunkowaniach rozwoju społeczno-gospodarczego uniemożliwienie uczniom realizacji przedmiotu o charakterze ekonomicznym na poziomie rozszerzonym i zdawania z niego matury jest wyjątkowo niekorzystne. Takie podejście do miejsca edukacji ekonomicznej (określanej także jako

${ }^{6}$ Pisownia oryginalna - w materiałach MEN dotyczących reformy nazwy przedmiotów zwykle są pisane zgodnie z zasadami pisowni polskiej - mała literą, czasem jednak... dużą. 
„biznesowa” bądź „w zakresie przedsiębiorczości”), jakże odmienne od podejścia w innych krajach wysoko rozwiniętych, stawia polską młodzież w wyjątkowo niekorzystnej sytuacji, obniżając zdecydowanie jej konkurencyjność wobec rówieśników z innych krajów. Objawiać się to może szczególnie niekorzystnie $\mathrm{w}$ zakresie możliwości wejścia młodego pokolenia na krajowy i międzynarodowy rynek pracy oraz konkurowania na polu biznesu, szczególnie na jednolitym rynku Unii Europejskiej. Efekty niskiego poziomu edukacji ekonomicznej, związane $\mathrm{z}$ brakiem możliwości realizacji $\mathrm{w}$ szerszym zakresie treści związanych $\mathrm{z}$ funkcjonowaniem rynków finansowych, uwidoczniły się szczególnie w ostatnich miesiącach, kiedy kryzys na światowych rynkach finansowych dotknął w szczególny sposób wiele społeczeństw, w tym także polskie. Obnażona została niewiedza i naiwność przeciętnych klientów usług finansowych, którzy w panice wycofywali oszczędności zainwestowane w nieco bardziej ryzykowne instrumenty finansowe, pogłębiając niekorzystne tendencje na rynku kapitałowym i pogarszając swoją sytuację finansową. Przy okazji wielu z nich boleśnie odczuło skutki braku umiejętności czytania umów zawieranych $\mathrm{z}$ instytucjami finansowymi bądź rozumienia mechanizmów ich funkcjonowania, w efekcie wielu $\mathrm{z}$ nich, wraz $\mathrm{z}$ akceptacją strat inwestycyjnych, miało silne poczucie frustracji wynikającej z rzekomo „oszukańczych” działań tych instytucji. Wskazuje to na potrzebę natychmiastowego zwiększenia liczby godzin przeznaczonych na edukację ekonomiczną i rozpoczęcie jej już od szkoły podstawowej. Niestety, projekt podstawy jest pod tym względem wyjątkowo zachowawczy. Zamiast być istotnym krokiem naprzód, który właśnie wykonuje wiele krajów europejskich, uświadamiających sobie skutki zbyt niskiego poziomu edukacji w tym zakresie, jest swoistym „dreptaniem w miejscu”, jeśli nie krokiem wstecz, zważywszy na współczesne wyzwania cywilizacyjne i działania innych krajów.

\section{Profilowanie a efekty kształcenia w ramach przedsiębiorczości}

Projektodawcy reformy zwrócili szczególną uwagę na znaczenie wyboru odpowiedniego profilu dalszego kształcenia przez uczniów I klasy szkoły ponadgimnazjalnej. W poradniku dla dyrektorów czytamy (Poradnik..., 2008): „Profilowanie jest procesem wspierającym ucznia w dokonywaniu wyboru własnej drogi edukacji. Najważniejszymi aspektami profilowania jest:

- w gimnazjum - rozpoznanie mocnych i słabych stron ucznia, pomoc w wyborze profilu kształcenia w szkole ponadgimnazjalnej,

- w liceum - monitoring trafności wyboru danego profilu przez ucznia; pomoc w dokonaniu wyborów maturalnych i dookreśleniu drogi dalszego kształcenia.

Jednymi z najtrudniejszych decyzji podejmowanych przez ucznia w toku nauki są kwestie związane z dobrym rozpoznaniem swoich mocnych i słabych stron [podkreślenie T.R.] oraz świadomym wyborem konkretnego profilu kształcenia. Pochopny i nie do końca przemyślany wybór, na przykład przedmiotów realizowanych w liceum w rozszerzonej wersji programowej czy też zdawanych w ramach egzaminu maturalnego, może istotnie utrudnić realizację marzeń o wykonywaniu określonego zawodu.

$\mathrm{W}$ projekcie zauważalny jest jednak zupełny brak powiązania profilowania w szkole ponadgimnazjalnej z treściami kształcenia w zakresie analizy mocnych i słabych stron własnej osobowości. Efekty kształcenia w tym zakresie zostały zaplanowane w ramach treści kształcenia podstaw przedsiębiorczości (,[uczeń] rozpoznaje mocne i słabe strony własnej osobowości; odnosi je do cech osoby przedsiębiorczej") na IV etapie edukacyjnym (szkoła ponadgimnazjalna!) z propozycją (według poradnika MEN) realizacji tego punktu podstawy programowej w... II klasie (!), a więc po wybraniu przez ucznia profilu kształcenia. Takie usytuowanie zapisów dotyczących osiągania w czasie tych efektów kształcenia w podstawie programowej należy więc uznać za nieporozumienie. 


\section{Uwagi do rozkładu grup treści programowych z zakresu przedsiębiorczości między III a IV etap edukacyjny}

W ramach przedmiotu wiedza o społeczeństwie realizowanego na III etapie edukacyjnym (gimnazjum) przewidziano następujące grupy treści nauczania z zakresu przedsiębiorczości (numeracja według projektu):

24. Praca i przedsiębiorczość.

25. Gospodarka rynkowa.

26. Gospodarstwo domowe.

27. Pieniądz i banki.

28. Gospodarka w skali państwa.

29. Przedsiębiorstwo i działalność gospodarcza.

30. Wybór szkoły i zawodu.

31. Etyka w życiu gospodarczym.

a także grupy treści częściowo związane z problematyką przedsiębiorczości:

20. Integracja europejska (w tym m.in. budżet UE).

21. Polska w Unii Europejskiej (w tym m.in. fundusze unijne).

23. Problemy współczesnego świata (w tym m.in. globalizacja gospodarki).

Grupy treści w ramach przedmiotu podstawy przedsiębiorczości realizowanego na IV etapie edukacyjnym (szkoła ponadgimnazjalna) obejmują następujące pozycje:

1. Człowiek przedsiębiorczy.

2. Rynek - cechy i funkcje.

3. Instytucje rynkowe.

4. Państwo, gospodarka.

5. Przedsiębiorstwo.

6. Rynek pracy.

Już wstępna analiza rozkładu grup treści między te dwa poziomy edukacji wskazuje, że zakres treści nauczania dla gimnazjum (przy uwzględnieniu faktu, że nauczyciel WOS ma do dyspozycji tylko 60 godz. na cały przedmiot, w tym teoretycznie 15-20 godz. na wymienione wyżej treści związane z przedsiębiorczością) jest zbyt szeroki w stosunku do zakresu, jaki przewidziano dla szkoły ponadgimnazjalnej (60 godz.). Pomijając niefortunne sformułowania określające dwie grupy treści w gimnazjum: „Gospodarka rynkowa - Gospodarka w skali [? - T.R.] państwa” (dlaczego te dwa punkty są rozdzielone?), należy zwrócić uwagę, że problematyka prowadzenia działalności gospodarczej (punkt 29) jest zbyt poważnym zagadnieniem i powinna być przeniesiona z gimnazjum do szkoły ponadgimnazjalnej. Ponadto, ze względu na ograniczoną liczbę godzin, albo treści z zakresu przedsiębiorczości powinny być całkowicie wyłączone do osobnego przedmiotu (co najmniej 30 godz. na realizację), albo część z nich również powinna zostać przeniesiona do szkoły ponadgimnazjalnej (wydaje się, że najodpowiedniejsze do przeniesienia są punkty 28 - Pieniądz i banki oraz 31 - Etyka w życiu gospodarczym). Natomiast w szkole ponadgimnazjalnej zupełnie zbędne wydają się treści związane z człowiekiem przedsiębiorczym (punkt 1), które powinny rozpoczynać edukację w zakresie przedsiębiorczości, tzn. być realizowane w gimnazjum (jeśli nie już w szkole podstawowej na II etapie edukacyjnym). Podobnie cechy rynku i jego instytucje (punkty 2 i 3 ) mogłyby być realizowane na wcześniejszym etapie edukacji. Ewidentnie brakuje na tym etapie kształcenia treści związanych z prowadzeniem działalności gospodarczej oraz ochroną klienta usług finansowych. Zastrzeżenia budzi też niefortunne nazewnictwo treści w szkole ponadgimnazjalnej: grupy treści oznaczone jako 2 i 3 mogłyby zostać połączone, bo przecież instytucje rynkowe (jak sama nazwa wskazuje) są częścią rynku; użycie przecinka w grupie treści 4 - Państwo, gospodarka wskazuje zaś na niedbałość bądź 
nierozumienie przez autorów relacji między tymi pojęciami. Wydaje się to zresztą zbędnym powtórzeniem grupy treści nauczania występujących w gimnazjum („Gospodarka w skali państwa").

Wynika to - jak się wydaje - z braku jakiejkolwiek koncepcji rozdzielenia treści nauczania z zakresu przedsiębiorczości pomiędzy III i IV edukacyjny. Trudno się oprzeć wrażeniu, że części te były tworzone przez dwa zupełnie niewspółpracujące ze sobą zespoły (chociaż teoretycznie stworzony był jeden do danej grupy przedmiotów). Jest to niezgodne ze wspomnianymi wcześniej podstawowymi założeniami projektowanej reformy programowej, w której, jak wskazano w jej uzasadnieniu: ,proponuje się zlączenie programowe gimnazjum i szkoły ponadgimnazjalnej, którego celem jest unowocześnienie programu szkoły i uniknięcie dwukrotnej, pospiesznej realizacji tych samych treści programowych [podkreślenie T.R.]. Z dotychczasowych doświadczeń wynika bowiem, że okres 3 lat jest zbyt krótki, by pomieścić w nim pełny cykl kształcenia ogólnego i uzyskać satysfakcjonujące efekty kształcenia. Proponowane złączenie programowe gimnazjum i szkoły ponadgimnazjalnej, polegające na wydłużeniu powszechnego kształcenia w gimnazjum o przynajmniej rok kształcenia w szkole ponadgimnazjalnej, spowoduje, że w ciągu kształcenia w gimnazjum i w szkole ponadgimnazjalnej uczniowie uzyskają solidne podstawy wiedzy i umiejętności w każdej dziedzinie kształcenia" (Uzasadnienie..., 2008).

Analiza projektu wskazuje jednak na brak lub wyraźną niejednoznaczność kryteriów podziału treści nauczania między III i IV etap edukacyjny (gimnazjum - szkoła ponadgimnazjalna), powodujący czasem zbyt wygórowane założenia dotyczące efektów kształcenia w gimnazjum i zbyt banalne w szkole ponadgimnazjalnej oraz „dwukrotną, pospieszną” realizację wielu tych samych treści, choć jest to sprzeczne z fundamentalnymi założeniami reformy.

Ilość zbędnych powtórzeń treści w gimnazjum i szkole ponadgimnazjalnej (lub zbyt zbliżonych merytorycznie zakładanych efektów kształcenia, które nie powinny być rozdzielone między te dwa etapy edukacyjne), niepozwalająca na realizację wielu treści brakujących w podstawie programowej i ograniczająca czas, jaki mają do dyspozycji nauczyciele, jest wyjątkowo duża (tab. 1).

Ponadto należy zauważyć, że „cele kształcenia - wymagania ogólne”, pogrupowane w 4 części, tzn.:

- Komunikacja i podejmowanie decyzji.

- Gospodarka i przedsiębiorstwo.

- Planowanie i kariera zawodowa.

- Zasady etyczne,

nie do końca odpowiadają zapisom efektów kształcenia (tzn. treściom nauczania i umiejętnościom - wymagania szczegółowe). Sprawia to mylne wrażenie, jakby nacisk położony był na te 4 cele. A przecież „komunikacja i podejmowanie decyzji” oraz „zasady etyczne” w porównaniu z pozostałymi dwoma celami zostały w zapisach wymagań szczegółowych potraktowane marginalnie, trudno więc uznać je za podstawowe wymagania ogólne. Niefortunny jest też zapis celu zatytułowanego „gospodarka i przedsiębiorstwo” sugerujący, przez użycie spójnika „i”, jakby były to „równorzędne” pojęcia, a przedsiębiorstwa nie były częścią gospodarki.

\section{Uwagi szczegółowe do zapisów treści kształcenia}

Analiza szczegółowych zapisów treści (efektów?) kształcenia (zatytułowanych, jak już zostało wspomniane, w dość osobliwy i przez to niezbyt zrozumiały sposób jako ,treści nauczania i umiejętności - wymagania szczegółowe”) wskazuje również, że w niektórych wypadkach treści z zakresu przedsiębiorczości realizowane w gimnazjum w ramach WOS powinny zostać przeniesione do IV etapu edukacyjnego lub realizowane na tym poziomie edukacji tylko 
Tab. 1. Wykaz zbędnych powtórzeń7 treści nauczania i umiejętności w gimnazjum i szkole ponadgimnazjalnej

\begin{tabular}{|c|c|}
\hline $\begin{array}{c}\text { Gimnazjum } \\
\text { (treści z zakresu przedsiębiorczości w WOS) }\end{array}$ & $\begin{array}{c}\text { Szkoła ponadgimnazjalna } \\
\text { (podstawy przedsiębiorczości) }\end{array}$ \\
\hline $\begin{array}{l}\text { 24. Praca i przedsiębiorczość. Uczeń: }(. . .) \\
\text { 2) przedstawia cechy i umiejętności człowieka } \\
\text { przedsiebbiorczego; bierze udział } \\
\text { w przedsięwzięciach społecznych, } \\
\text { które pozwalają je rozwinąć; }\end{array}$ & $\begin{array}{l}\text { 1. Człowiek przedsiębiorczy. Uczeń: } \\
\text { 1) przedstawia cechy, jakimi charakteryzuje } \\
\text { się osoba przedsiębiorcza; }\end{array}$ \\
\hline $\begin{array}{l}\text { 27. Pieniądz i banki. Uczeń: } \\
\text { 1) przedstawia na przykładach funkcje i formy } \\
\text { pieniadza w gospodarce rynkowej; } \\
\text { 2) wyjaśnia, czym zajmuja się: bank centralny, } \\
\text { banki komercyjne, giełda papierów } \\
\text { wartościowych; } \\
\text { 3) porównuje oferty różnych banków (konta, } \\
\left.\text { lokaty, kredyty, fundusze inwestycyjne }{ }^{8}\right) \text {. }\end{array}$ & $\begin{array}{l}\text { 3. Instytucje rynkowe. Uczeń: } \\
\text { 1) } \text { rozróżnia formy i funkcje pieniadza }^{9} \text {; } \\
\text { 2) } \underline{\text { wyjaśnia role, jaka w gospodarce pełnia }} \\
\text { instytucje rynkowe: bank centralny, banki } \\
\text { komercyjne, giełda papierów wartościowych } \\
\text { fundusze inwestycyjne, firmy ubezpiecze- } \\
\text { niowe, fundusze emerytalne; (...) } \\
\text { 8) analizuje oferty funduszy inwestycyjnych, firm } \\
\text { ubezpieczeniowych i funduszy emerytalnych. }\end{array}$ \\
\hline $\begin{array}{l}\text { 25. Gospodarka rynkowa. Uczeń: (...) } \\
\text { 4) wyjaśnia działanie prawa podaży i popytu } \\
\text { oraz ceny jako regulatora rynku; analizuje } \\
\text { rynek wybranego produktu i wybranej } \\
\text { usługi. }\end{array}$ & $\begin{array}{l}\text { 2. Rynek - cechy i funkcje. Uczeń: (...) } \\
\text { 6) charakteryzuje czynniki wpływajace na } \\
\text { popyt i podaż; } \\
\text { 7) wyznacza punkt równowagi rynkowej na } \\
\text { prostym przykładzie. }\end{array}$ \\
\hline $\begin{array}{l}\text { 28. Gospodarka w skali }{ }^{10} \text { państwa. Uczeń: } \\
\text { 1) wyjaśnia terminy: produkt krajowy brutto, } \\
\text { wzrost gospodarczy, inflacja; interpretuje } \\
\text { dane statystyczne na ten temat; } \\
\text { 2) wymienia najważniejsze dochody i wydatki } \\
\text { państwa; wyjaśnia, co to jest budżet państwa; } \\
\text { 3) przedstawia główne rodzaje podatków } \\
\text { w Polsce (PIT, VAT, CIT }{ }^{11} \text { ) i oblicza } \\
\text { wysokość podatku PIT na podstawie } \\
\text { konkretnych danych. }\end{array}$ & $\begin{array}{l}\text { 4. Państwo, gospodarka. Uczeń: (...) } \\
\text { 2) opisuje podstawowe mierniki wzrostu } \\
\text { gospodarczego; (...) } \\
\text { 4) wymienia źródła dochodów i rodzaje } \\
\text { wydatków państwa; } \\
\text { 6. Rynek pracy. Uczeń: }(. .) \\
\text { 7) charakteryzuje różne formy wynagrodzeń } \\
\text { i oblicza swoje wynagrodzenie brutto } \\
\text { i netto; wypełnia deklaracje podatkowa PIT, } \\
\text { opierajac sie na przykładowych danych; }\end{array}$ \\
\hline $\begin{array}{l}\text { 29. Przedsiębiorstwo i działalność gospodarcza. } \\
\text { Uczeń: } \\
\text { 1) wyjaśnia, jak się zakłada i prowadzi } \\
\text { indywidualną działalność gospodarczą; }\end{array}$ & 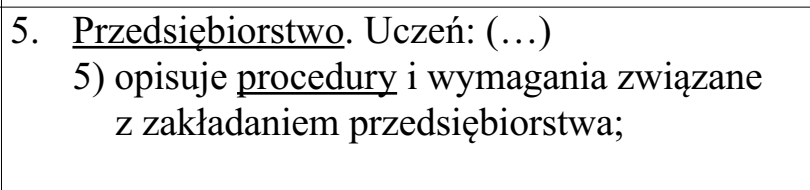 \\
\hline
\end{tabular}

${ }^{7} \mathrm{~W}$ wykazie podkreślono również zbyt zbliżone merytorycznie zakładane efekty kształcenia, dla których rozdzielenia między III i IV etap edukacyjny, jak się wydaje, nie ma uzasadnienia merytorycznego i powinny być realizowane „obok siebie”, w logicznym następstwie treści (oczywiście przy założeniu MEN, że idea „złączenia programowego” jest słuszna, co - jak wiadomo - spotkało się z krytyką wielu specjalistów). ${ }^{8}$ Rodzi się poważna wątpliwość, czy „fundusz inwestycyjny” to „oferta” banku. Chociaż rzeczywiście wiele banków oferuje w swoich oddziałach możliwość zainwestowania w ,fundusze”, to przecież nie jest to de facto oferta banku (który takiej działalności, zarezerwowanej dla TFI, prowadzić nie może). Autorzy podstawy zdają sobie z tego zapewne sprawę, jest to więc kolejny przykład na nieprecyzyjność zapisów, który w tego typu dokumencie, jakim jest podstawa programowa, jest absolutnie niedopuszczalny.

${ }^{9}$ Warto się zastanowić, czy pieniądz jest ,instytucją rynkową”, jak wskazuje nazwa grupy treści kształcenia.

${ }^{10} \mathrm{Na}$ marginesie należy zauważyć niezbyt fortunne określenie „,w skali [państwa]”.

${ }^{11}$ Podatek PIT, który jest na pierwszym miejscu, wcale nie jest „głównym” podatkiem, jeśli chodzi o dochody budżetu państwa. Podatki powinny być wymienione albo w kolejności alfabetycznej (CIT, PIT, VAT), albo według znaczenia w budżecie państwa (VAT na pierwszym miejscu). Powstaje też wątpliwość, dlaczego nie wymieniono podatku akcyzowego, którego znaczenie jest większe niż znaczenie CIT. 
Tab. 1. (dok.)

\begin{tabular}{|c|c|}
\hline $\begin{array}{c}\text { Gimnazjum } \\
\text { (treści z zakresu przedsiębiorczości w WOS) }\end{array}$ & $\begin{array}{c}\text { Szkoła ponadgimnazjalna } \\
\text { (podstawy przedsiębiorczości) }\end{array}$ \\
\hline $\begin{array}{l}\text { 30. Wybór szkoły i zawodu. Uczeń: (...) } \\
\text { 3) sporzadza życiorys i list motywacyjny; } \\
\text { 4) wskazuje główne przyczyny bezrobocia } \\
\text { w swojej miejscowości, regionie i Polsce; } \\
\text { ocenia jego skutki. }\end{array}$ & $\begin{array}{l}\text { 6. Rynek pracy. Uczeń: } \\
\text { 1) omawia mierniki i skutki bezrobocia } \\
\text { dla gospodarki oraz sposoby walki } \\
\text { z bezrobociem (...) } \\
\text { 5) } \underline{\text { sporzadza dokumenty aplikacyine }} \\
\text { dotyczące konkretnej oferty pracy; }\end{array}$ \\
\hline $\begin{array}{l}\text { 31. Etyka w życiu gospodarczym. Uczeń: } \\
\text { 1) przedstawia zasady etyczne, którymi } \\
\text { powinni sie kierować pracownicy } \\
\text { i pracodawcy; wyjaśnia, na czym polega } \\
\text { społeczna odpowiedzialność biznesu; }\end{array}$ & $\begin{array}{l}\text { 5. Przedsiębiorstwo. Uczeń: }(\ldots) \\
\text { 10) charakteryzuje zachowania etyczne } \\
\text { i nieetyczne w biznesie krajowym } \\
\text { i międzynarodowym; } \\
\text { 6. Rynek pracy. Uczeń: }(\ldots) \\
\text { 8) rozróżnia zachowania etyczne i nieetyczne } \\
\text { w roli pracodawcy i pracownika. }\end{array}$ \\
\hline
\end{tabular}

w przypadku stworzenia osobnego przedmiotu podstawy przedsiębiorczości, który będzie miał przydzieloną odpowiednią, adekwatną do zakładanych efektów kształcenia, liczbę godzin (tab. 2). Ale nawet w przypadku wydzielenia osobnego przedmiotu w gimnazjum, należałoby istotnie przebudować układ treści, tak by fundamentalne dla projektu reformy ,złączenie programowe gimnazjum i szkoły ponadgimnazjalnej” w zakresie przedsiębiorczości było realizowane sensownie, zgodnie $\mathrm{z}$ logicznym następstwem treści. W zaprezentowanym projekcie podstawy programowej nie tylko zauważa się zbędne powtórzenia treści, ale także wyraźne niedopasowanie wielu efektów kształcenia do poziomu edukacyjnego. $Z$ jednej strony pojawiają się więc zbyt trudne do osiągnięcia w gimnazjum efekty kształcenia (przy założeniu, że nie jest to osobny przedmiot z większą liczbą godzin i nie poprzedza go realizacja żadnych treści z zakresu przedsiębiorczości w szkole podstawowej), z drugiej zaś na poziomie szkoły ponadgimnazjalnej zakładane efekty są czasem tak banalne (np. [uczeń] przedstawia cechy, jakimi charakteryzuje się osoba przedsiębiorcza), że z powodzeniem mogłyby być przeniesione na niższy poziom edukacji.

Tab. 2. Wykaz nieadekwatnych do danego poziomu edukacyjnego treści nauczania i umiejętności

\begin{tabular}{|c|c|}
\hline $\begin{array}{c}\text { Gimnazjum } \\
\text { (treści z zakresu przedsiębiorczości } \\
\text { w WOS, które powinny zostać przeniesione } \\
\text { do IV etapu edukacyjnego) }\end{array}$ & $\begin{array}{c}\text { Szkoła ponadgimnazjalna } \\
\text { (podstawy przedsiębiorczości - treści zbyt } \\
\text { banalne, które powinny zostać przeniesione } \\
\text { do III etapu edukacyjnego) }\end{array}$ \\
\hline $\begin{array}{l}\text { 24. Praca i przedsiębiorczość. Uczeń: } \\
\text { 3) stosuje w praktyce podstawowe zasady } \\
\text { organizacji pracy (ustalenie celu, } \\
\text { planowanie, podział zadań, harmonogram. } \\
\text { ocena efektów). }\end{array}$ & 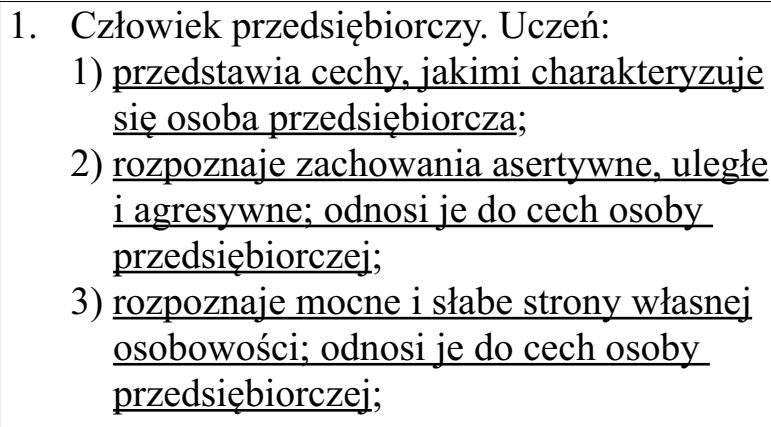 \\
\hline $\begin{array}{l}\text { 28. Gospodarka w skali państwa. Uczeń: } \\
\text { 1) wyjaśnia terminy: produkt krajowy brutto, } \\
\text { wzrost gospodarczy, inflacja; interpretuje } \\
\text { dane statystyczne na ten temat; }\end{array}$ & $\begin{array}{l}\text { 4. Państwo, gospodarka. Uczeń: (...) } \\
\text { 2) opisuje podstawowe mierniki wzrostu } \\
\text { gospodarczego; (...) } \\
\text { 4) wymienia źródła dochodów i rodzaje } \\
\text { wydatków państwa; }\end{array}$ \\
\hline
\end{tabular}


Tab. 2. (dok.)

\begin{tabular}{|c|c|}
\hline $\begin{array}{c}\text { Gimnazjum } \\
\text { (treści z zakresu przedsiębiorczości } \\
\text { w WOS, które powinny zostać przeniesione } \\
\text { do IV etapu edukacyjnego) }\end{array}$ & $\begin{array}{c}\text { Szkoła ponadgimnazjalna } \\
\text { (podstawy przedsiębiorczości - treści zbyt } \\
\text { banalne, które powinny zostać przeniesione } \\
\text { do III etapu edukacyjnego) }\end{array}$ \\
\hline $\begin{array}{l}\text { 29. Przedsiębiorstwo i działalność gospodarcza. } \\
\text { Uczeń: } \\
\text { 1) wyjaśnia, jak się zakłada i prowadzi } \\
\text { indywidualną działalność gospodarczą; (...) } \\
\text { 3) wskazuje główne elementy działań } \\
\text { marketingowych (produkt, cena, miejsce, } \\
\text { promocja) i wyjaśnia ich znaczenie dla } \\
\text { przedsiebiorstwa i konsumentów; }\end{array}$ & $\begin{array}{l}\text { 5. Przedsiębiorstwo. Uczeń: } \\
\text { 1) charakteryzuje otoczenie, w którym działa } \\
\text { przedsiębiorstwo; } \\
\text { 5) opisuje procedury i wymagania związane } \\
\text { z zakładaniem przedsiębiorstwa; (...) } \\
\text { 11) charakteryzuje czynniki wpływajace na } \\
\text { sukces i niepowodzenie przedsiębiorstwa. }\end{array}$ \\
\hline $\begin{array}{l}\text { 30. Wybór szkoły i zawodu. Uczeń: (...) } \\
\text { 2) wyszukuje informacje o możliwościach } \\
\text { zatrudnienia na lokalnym, regionalnym, } \\
\text { krajowym i europejskim rynku pracy } \\
\text { (urzędy pracy, ogłoszenia, Internet); }\end{array}$ & $\begin{array}{l}\text { 6. Rynek pracy. Uczeń: (...) } \\
\text { 2) wyjaśnia motywy aktywności zawodowej } \\
\text { człowieka; }\end{array}$ \\
\hline $\begin{array}{l}\text { 31. Etyka w życiu gospodarczym. Uczeń: } \\
\text { 1) przedstawia zasady etyczne, którymi } \\
\text { powinni się kierować pracownicy } \\
\text { i pracodawcy; wyjaśnia, na czym polega } \\
\text { społeczna odpowiedzialność biznesu; } \\
\text { 2) podaje przykłady zjawisk z szarej strefy } \\
\text { w gospodarce i poddaje je ocenie; } \\
\text { 3) wyjaśnia mechanizm korupcji i ocenia } \\
\text { skutki tego zjawiska dla gospodarki. }\end{array}$ & $\begin{array}{l}\text { 6. Rynek pracy. Uczeń: }(\ldots) \\
\text { 8) } \underline{\text { rozróżnia zachowania etyczne i nieetyczne }} \\
\text { w roli pracodawcy i pracownika. }\end{array}$ \\
\hline
\end{tabular}

W projekcie zauważa się ponadto wiele niezbyt precyzyjnych zapisów zakładanych efektów kształcenia (wymagań szczegółowych). Oprócz wspomnianych wcześniej nieścisłości (dotyczących funduszy inwestycyjnych jako oferty banku), należy wskazać inne niejasne zapisy (etap gimnazjum):

- [uczeń] wyjaśnia, jak się zakłada i prowadzi indywidualną działalność gospodarczą - w jaki sposób autorzy wyobrażają sobie wyjaśnienie ,jak prowadzi się działalność”? czy ma to być np. opis procesu zarządzania przedsiębiorstwem?

- [uczeń] wyjaśnia terminy: produkt krajowy brutto, wzrost gospodarczy, inflacja; interpretuje dane statystyczne na ten temat - co oznacza sformułowanie ,na ten temat” i do czego się odnosi: do terminów?

- [uczeń] przedstawia podmioty gospodarcze (gospodarstwa domowe, przedsiębiorstwa, państwo) i związki między nimi - dla nauczycieli niezrozumiałe może być sformułowanie „przedstawia” (np. państwo), poza tym powstaje wątpliwość, czy państwo jest „podmiotem gospodarczym” (raczej ,podmiotem gospodarki”);

- [uczeń] wskazuje główne przyczyny bezrobocia w swojej miejscowości, regionie i Polsce; ocenia jego skutki - czy konieczne jest rozróżnienie skal przestrzennych (szczególnie regionalnej i krajowej)? Czy uczeń gimnazjum powinien rozróżniać przyczyny bezrobocia w województwie od przyczyn bezrobocia w kraju, skoro w rzeczywistości są one bardzo podobne, a ich precyzyjna hierarchizacja w zależności od skali przestrzennej wymaga badań naukowych i operowania dosyć precyzyjnymi narzędziami metodologicznymi i zaawansowanym aparatem pojęciowym? 
W zapisach wymagań w szkole ponadgimnazjalnej w ramach przedmiotu podstawy przedsiębiorczości wątpliwości mogą budzić następujące zapisy:

- [uczeń] podejmuje racjonalne decyzje, opierając się na posiadanych informacjach i ocenia skutki własnych działań - zbyt ogólne i zbyt szerokie określenie: czy jesteśmy w stanie sprawdzić efekty kształcenia w zakresie tak sformułowanego wymagania, czy podejmowania racjonalnych decyzji i oceniania skutków własnych działań człowiek nie uczy się w zasadzie przez całe życie?

- [uczeń] przedstawia przyczyny i narzędzia oddziaływania państwa na gospodarkę - niejasne może być dla nauczycieli, co autorzy rozumieją pod pojęciem ,przyczyny” i jak szeroko należy ujmować „narzędzia oddziaływania” (jest to zbyt szeroka problematyka polityki gospodarczej);

- [uczeń] sporządza projekt własnego przedsiębiorstwa oparty na biznesplanie - co to znaczy, że projekt jest „oparty” na biznesplanie? Chyba chodzi o umiejętności zapisu projektu w postaci (formie) biznesplanu?

- [uczeń] ocenia sytuację finansową przedsiębiorstwa, posługując się bilansem przedsiębiorstwa oraz podstawowymi wskaźnikami finansowymi - czy wprowadzając słowo „,bilans” autorzy mają na myśli umiejętność czytania sprawozdań finansowych przedsiębiorstw tworzonych zgodnie $\mathrm{z}$ wymogami ustawy o rachunkowości i jeśli tak, to przy tej liczbie godzin zapoznanie uczniów z tzw. pełną rachunkowością wydaje się niemożliwe, wprowadzanie zaś niektórych elementów (np. bilansu bez sprawozdania z przepływów środków pieniężnych) wydaje się bezcelowe.

Nieprecyzyjne zapisy występują także w projekcie podstawy programowej przedmiotu ekonomia w praktyce, np.: [uczeń] ocenia możliwości realizacji przedsięwzięcia o podobnym charakterze na gruncie realnej gospodarki rynkowej. Wątpliwości budzi sformułowanie „realna”: po pierwsze, warto się zastanowić, czy istnieje „nierealna” gospodarka rynkowa, po drugie, czy to ma oznaczać, że przedsięwzięcie uczniowskie nie jest realizowane „w praktyce” (jak wskazuje nazwa przedmiotu), a jedynie w formie „teoretycznego” projektu? Należy wiec zapytać o cel tego przedmiotu, gdyż w zapisie projektu podstawy programowej jest on niejasny. Jeśli uczniowie mają tylko przygotowywać plan przedsięwzięcia (a nie realizować go „w praktyce”), to nasuwa się pytanie, czym ma to się różnić od postawionego w przedmiocie podstawy przedsiębiorczości wymagania związanego z zaprojektowaniem własnej działalności gospodarczej w formie biznesplanu. Taki biznesplan może być wykonywany w ramach zajęć z tego przedmiotu przez grupę uczniów, byłoby to zatem planowanie wspólnego przedsięwzięcia uczniowskiego. Przy tak sformułowanych zapisach wydaje się to jedynie rozszerzeniem problematyki związanej z planowaniem działalności własnej firmy, stąd wątpliwość: po co tworzyć osobny przedmiot? Bardziej racjonalne wydaje się połączenie go z podstawami przedsiębiorczości (łącznie byłoby to 90 godz.) i powiązanie realizowanej na nim problematyki z treściami dotyczącymi zakładania i prowadzenia własnej działalności gospodarczej, zwłaszcza jeśli przedsięwzięcie nie ma być realizowane „w praktyce”, a jedynie w formie planu. Jeśli zaś przyjmie się założenie, że to $\mathrm{w}$ ramach ekonomii $\mathrm{w}$ praktyce ma nastąpić przygotowanie uczniów do realizacji własnego pomysłu na przedsięwzięcie, to niecelowe wydaje się stawianie wymagań na podstawach przedsiębiorczości związanych z przygotowaniem biznesplanu.

Należy więc wyraźnie stwierdzić, że zamiast próby wprowadzenia nowego przedmiotu o niezbyt fortunnej nazwie, w dodatku pozostawiającej wątpliwości, czy może on być realizowany przez nauczycieli podstaw przedsiębiorczości ${ }^{12}$, należałoby dać uczniom możliwość

\footnotetext{
${ }^{12}$ Sprawa uznawalności kwalifikacji do nauczania tego „nowego” przedmiotu jest wbrew pozorom dosyć poważna, gdyż należy mieć na uwadze dotychczasową praktykę kwestionowania przez wielu dyrektorów szkół uprawnień nauczycieli przedmiotów ekonomicznych do uczenia podstaw przedsiębiorczości.
} 
realizacji tego przedmiotu na poziomie rozszerzonym (do wyboru, dla chętnych). To „rozszerzenie” przedmiotu mogłoby właśnie obejmować m.in. grupę treści związanych z zakładaniem i prowadzeniem własnej działalności gospodarczej w różnych formach oraz grupę treści związanych z głębszym poznaniem mechanizmów funkcjonowania rynków finansowych. W efekcie uczeń wybierający poziom rozszerzony byłby dobrze przygotowany do inwestowania środków pieniężnych w różnych formach, tzn. we własny biznes i na rynkach finansowych. Takie rozszerzenie treści kształcenia (przy założeniu, że uczniowie będą wyposażeni również w niezbędny zasób wiedzy teoretycznej z tego zakresu) umożliwiłoby też bezproblemowe wprowadzenie matury z podstaw przedsiębiorczości na poziomie podstawowym i rozszerzonym. Na możliwość przeprowadzenia egzaminu maturalnego wskazują sukcesy projektu „olimpiady z przedsiębiorczości” (która stała się takim ,egzaminem zewnętrznym”, dającym jednak możliwość dostania się na studia ekonomiczne tylko laureatom) oraz konkursy i turnieje $\mathrm{z}$ zakresu przedsiębiorczości organizowane w wielu szkołach i instytucjach edukacyjnych w całej Polsce.

W projekcie zauważa się też istotne braki w wymaganiach, które należałoby uzupełnić (tym bardziej, że można zaoszczędzić czas dzięki eliminacji zbędnych powtórzeń treści). Te braki zostały szerzej wypunktowane we wcześniejszej pracy (Rachwał, Kudełko, Tracz, Wach, Kilar 2008), w której zaprezentowano pełny projekt wersji podstawowej i rozszerzonej podstawy programowej i szczegółowo przeanalizowano propozycje nowych zapisów pod kątem współczesnych wyzwań rozwoju społeczno-gospodarczego. Warto jednak wskazać ważniejsze braki w zapisach analizowanego projektu podstawy programowej, dotyczące treści związanych z:

- kształtowaniem się społeczeństwa informacyjnego,

- rolą kapitału ludzkiego w warunkach gospodarki opartej na wiedzy,

- gospodarczymi skutkami integracji europejskiej oraz europejską swobodą działalności gospodarczej,

- ochroną klienta usług finansowych,

oraz w sytuacji, w której jako efekty kształcenia przyjmuje się: sporządzenie biznesplanu, znajomość procedur i wymagań związanych z zakładaniem przedsiębiorstwa (dlaczego nie likwidacją?) oraz znajomość elementów podstaw rachunkowości:

- procesu zarządzania przedsiębiorstwem,

- rozpoznawanie szans rynkowych,

- marketing i jego rola w funkcjonowaniu przedsiębiorstwa,

- majątek przedsiębiorstwa i źródła jego finansowania (sposoby pozyskania kapitału dla przedsiębiorstwa).

Warto podkreślić, że kwestia przygotowania do prowadzenia działalności gospodarczej jest bardzo poważna i powinna zostać rozstrzygnięta jednoznacznie. Twórcy nowej podstawy muszą sobie odpowiedzieć na pytanie, czy taki jest cel edukacji w zakresie przedsiębiorczości. Jeśli tak, to absolutnie nie można się ograniczyć do znajomości procedury rejestracji, form organizacyjno-prawnych, sporządzania uproszczonego biznesplanu i obliczania wybranych wskaźników finansowych. Można zaryzykować stwierdzenie, że w prowadzeniu biznesu są to

Nie ma się więc co dziwić, że w tej sytuacji nauczyciele podstaw przedsiębiorczości (absolwenci studiów podyplomowych z tego zakresu, niemający wykształcenia ekonomicznego sensu stricte) obawiają się, że nie będą mogli uczyć ekonomii w praktyce, co byłoby przecież irracjonalne. Obawy te są jednak uzasadnione, bo w pakiecie projektu reformy nie ma projektu rozporządzenia jednoznacznie regulującego tę kwestię. Niezrozumiałe wydaje się zatem, dlaczego ten „dodatkowy” przedmiot nie mógłby być traktowany jako rozszerzenie podstaw przedsiębiorczości (pod tą samą nazwą) lub po prostu być nazwanym przedsiębiorczość w praktyce, co zresztą bardziej odpowiadałoby idei tego przedmiotu i zapisom efektów kształcenia (gdzie właśnie o ,przedsiębiorczość”, a nie „ekonomię” chodzi). 
najmniej istotne kwestie, które zresztą można zlecić specjalistom z zewnątrz (prawnikowi rejestrację firmy, a księgowej - rachunkowość). Najważniejszy jest przecież pomysł na biznes, rozpoznanie szans rynkowych (przeprowadzenie badań rynkowych) i umiejętność zarządzania firmą (ze szczególnym uwzględnieniem zarządzania zasobami ludzkimi, problematyki marketingu i finansów przedsiębiorstwa), na co powinien być położony nacisk w zapisach podstawy programowej. Jeśli jednak nie miałoby to być celem przedmiotu, to wymagania związane $\mathrm{z}$ procedurą rejestracji czy sporządzaniem biznesplanu należałoby po prostu wykreślić, żeby nie sprawiać u uczniów błędnego wrażenia, że do tego tylko sprowadza się prowadzenie biznesu, bo jest to prosta droga do niepowodzenia w działalności gospodarczej, za co autorzy podstawy programowej i nauczyciele podstaw przedsiębiorczości winni czuć się choć w części odpowiedzialni.

Brak w podstawie programowej starannie przemyślanych zapisów, uwzględniających logiczne następstwo treści, odnoszących się do procesu zarządzania przedsiębiorstwem (bądź „przerzucanie” tych treści do nieobowiązkowego fakultatywnego przedmiotu ekonomia w praktyce), można uznać za sprzeczny z wyraźnymi zaleceniami Parlamentu Europejskiego i Rady w sprawie kompetencji kluczowych (Zalecenie..., 2006): „umiejętności [w zakresie przedsiębiorczości] odnoszą się do proaktywnego zarządzania projektami (co obejmuje np. planowanie, organizowanie, zarządzanie, kierowanie i zlecanie zadań, analizowanie, komunikowanie, sporządzanie raportów, ocenę i sprawozdawczość), skutecznej reprezentacji i negocjacji oraz zdolności zarówno do pracy indywidualnej, jak i do współpracy w zespołach”. Ponadto w znaczący sposób obniża to konkurencyjność absolwentów polskich szkół na europejskim rynku pracy, którzy będą gorzej przygotowani do pracy na stanowiskach kierowniczych w różnego typu firmach i instytucjach czy zarządzania założonymi przez siebie firmami, które mogłyby z powodzeniem konkurować na jednolitym rynku europejskim.

\section{Wnioski}

Analiza projektu zmian podstawy programowej kształcenia w zakresie przedsiębiorczości prowadzi do następujących wniosków:

- Deklaracje autorów projektu odnoszące się do przedsiębiorczości jako jednej z kompetencji kluczowych, dostosowania podstawy programowej współczesnych wyzwań rynku pracy, budowy gospodarki opartej na wiedzy i kształtowania się społeczeństwa informacyjnego (zawarte w uzasadnieniu projektu oraz poradniku dla dyrektorów i w materiałach promocyjnych reformy), nie mają odzwierciedlenia w rzeczywistych zapisach projektu rozporządzenia w zakresie podstawy programowej.

- W zaproponowanym kształcie podstawa programowa nie zapewnia więc możliwości pełnej realizacji zalecenia Parlamentu Europejskiego i Rady z dnia 18 grudnia 2006 r. w sprawie kompetencji kluczowych w procesie uczenia się przez całe życie (Zalecenie..., 2006) w odniesieniu do przedsiębiorczości, zgodnie z definicją tejże kompetencji przedstawioną w tym dokumencie.

- Widoczne są brak lub niejednoznaczność kryteriów podziału treści kształcenia między III i IV etap edukacyjny (gimnazjum - szkoła ponadgimnazjalna), czego efektem jest zapisanie wielu mało ambitnych treści, nieadekwatnych do poziomu szkoły ponadgimnazjalnej, oraz liczne powtórzenia w obydwu etapach edukacyjnych (co jest niezgodne z podstawowymi założeniami reformy). Jeśli rzeczywiście ,złączenie programowe” tych dwóch etapów edukacyjnych ma stać się faktem, podstawy przedsiębiorczości powinny być w gimnazjum osobnym przedmiotem, a zapisy wymagań powinny zostać przeprojektowane przez jeden zespół autorski pod względem układu treści, tak jakby były tworzone dla jednego etapu 
edukacyjnego. Tylko wtedy uda się uniknąć zbędnych powtórzeń i niewłaściwego następstwa treści.

- Zaletą projektu jest nacisk na wymagania, tzn. określenie treści nauczania w języku „efektów kształcenia”, chociaż w wielu wypadkach zapisy są niejednoznaczne, co powoduje, że nauczyciel nie może być pewny, jakie konkretnie efekty mają zostać osiągnięte.

- Zauważalne jest zbytnie przeciążenie treściami w gimnazjum (zakłada się za dużo efektów kształcenia jak na tak małą liczbę godzin, jaką ma do dyspozycji nauczyciel wiedzy o społeczeństwie; będzie to prowadzić do marginalizacji treści z zakresu przedsiębiorczości w realizacji przedmiotu).

- W podstawie programowej dla szkoły ponadgimnazjalnej brak co najmniej kilku kluczowych wymagań, które można wprowadzić po wyeliminowaniu powtórzeń.

- W obliczu kryzysu na rynkach finansowych należy wskazać istotne braki w projekcie w zakresie wymagań związanych z umiejętnością korzystania z usług instytucji finansowych. Konsekwencje zaniedbań edukacyjnych w tym zakresie widoczne są już dzisiaj, a będą bardziej dotkliwe, kiedy na polskim rynku pojawią się instytucje oferujące bardziej skomplikowane, zaawansowane produkty finansowe.

- Absolwenci zasadniczych szkół zawodowych, w przeciwieństwie do absolwentów szkół kończących się maturą, z reguły bezpośrednio po szkole trafiają na rynek pracy i próbują m.in. podjąć samozatrudnienie. Konieczne jest zatem wyposażenie ich w umiejętności niezbędne do realizacji wspólnych przedsięwzięć biznesowych. Należy zatem negatywnie ocenić brak możliwości wyboru i realizacji przez uczniów zasadniczej szkoły zawodowej ekonomii (dlaczego nie: przedsiębiorczości?) w praktyce. Za celowe natomiast należy uznać ujednolicenie podstawy programowej podstaw przedsiębiorczości w szkole ponadgminazjalnej kończącej się maturą i w zasadniczej szkole zawodowej.

- Wprowadzenie przedmiotu ekonomia w praktyce (o nieadekwatnej do realizowanych treści nazwie) zamiast możliwości realizacji podstaw przedsiębiorczości na poziomie rozszerzonym (dla chętnych), w świetle współczesnych wyzwań cywilizacyjnych i wymagań rynków pracy różnej skali należy ocenić jako nienajlepsze rozwiązanie.

- Przyjęcie zachowawczego podejścia (tzw. programu minimum) przy podejmowaniu zmian systemu edukacji w zakresie przedsiębiorczości, w szczególności dalsze uniemożliwianie uczniom realizacji tego przedmiotu na poziomie rozszerzonym i zdawania z niego matury, biorąc pod uwagę szczególne uwarunkowania, w jakich funkcjonuje polska gospodarka i w jakich polska młodzież wkracza w dorosłe życie, należy ocenić negatywnie. Zachowawczy program zmian należy również ocenić negatywnie w świetle zaleceń instytucji Unii Europejskiej oraz programu gospodarczego rządu polskiego, w którym jednym z priorytetów jest rozwój polskiej przedsiębiorczości, rozumianej jako dynamiczny wzrost sektora małych i średnich firm zakładanych przez obywateli. Trudno się spodziewać pozytywnych efektów w tym zakresie, jeśli nie ma odpowiedniego przygotowania do takich przedsiębiorczych zachowań w ramach systemu powszechnej edukacji.

- Warto podkreślić zdecydowanie większą dbałość autorów (w porównaniu z poprzednimi projektami zmian podstawy programowej i podstawą aktualnie obowiązującą) o poprawność merytoryczną i precyzyjność zapisów efektów kształcenia, chociaż należy zauważyć, że niektóre z nich wymagają korekty. W projekcie jest bowiem zbyt wiele niefortunnych i niejasnych sformułowań (niezręczności językowych), które należy wyeliminować.

$\mathrm{Na}$ zakończenie należy z całą mocą podkreślić, że u podstaw głębokiej troski o kształt nowej podstawy programowej w zakresie przedsiębiorczości leży nie tylko przywoływana wyżej kwestia pomyślnego rozwoju społeczno-gospodarczego naszego kraju (por. Zioło 2006, 
2007). Najważniejsza jest w tym wszystkim troska o polską młodzież, każdego młodego człowieka, który wkrótce wkroczy w dorosłość i - przechodząc do etapu życia zawodowego - będzie musiał wziąć odpowiedzialność za byt swój i założonej przez siebie rodziny. Nie chodzi tu tylko o satysfakcję $\mathrm{z}$ pracy i powodzenie $\mathrm{w}$ realizacji poszczególnych etapów kariery zawodowej, ale także o udane życie osobiste i rodzinne, zgodnie z przyjętą szeroką definicją przedsiębiorczości (Rachwał 2005a, b). Na ten aspekt kształcenia w zakresie przedsiębiorczości zwrócono także uwagę w przywoływanym stanowisku Parlamentu Europejskiego i Rady (Zalecenie ..., 2006), w którym stwierdza się, że ,,postawa przedsiębiorcza charakteryzuje się inicjatywnością, aktywnością, niezależnością i innowacyjnością zarówno w życiu osobistym i społecznym, jak i w pracy. Obejmuje również motywację i determinację w kierunku realizowania celów, czy to osobistych, czy wspólnych, zarówno prywatnych jak i w pracy".

Ukształtowanie postawy przedsiębiorczej jest więc dla młodego pokolenia sprawą kluczową i stanowi wielką powinność zarówno dla nas - nauczycieli, jak i wszelkich decydentów mających wpływ na edukację ekonomiczną na szczeblu krajowym. Wydaje się, że uwzględnienie przedstawionych wyżej uwag i sugestii może wpłynąć na udoskonalenie podstawy programowej i nowy kształt edukacji w zakresie przedsiębiorczości w Polsce, adekwatny do współczesnych wyzwań cywilizacyjnych związanych z kształtowaniem społeczeństwa informacyjnego i gospodarowaniem opartym na wiedzy.

\section{Literatura}

1. Baran B., 2005, Problematyka rynku pracy w edukacji przedsiębiorczości [w:] Przedsiębiorczość a wspótczesne wyzwania edukacyjne, Z. Zioło, T. Rachwał (red.), Przedsiębiorczość - Edukacja $n r$ 1, Kraków, s. 227-238.

2. Bartoń M., 2005, Przedsiębiorczość jako przedmiot matury 2008 [w:] Przedsiębiorczość a współczesne wyzwania edukacyjne, Z. Zioło, T. Rachwał (red.), Przedsiębiorczość - Edukacja nr 1, Kraków, s. $255-258$.

3. Batorska U., 2005, Rodzaje i struktura bezrobocia w Polsce [w:] Przedsiębiorczość a współczesne wyzwania edukacyjne, Z. Zioło, T. Rachwał (red.), Przedsiębiorczość - Edukacja nr 1, Kraków, s. 239-251.

4. Bielecka M., 2005, Podstawy przedsiębiorczości: poradnik dla nauczyciela, Żak - Wydawnictwo Edukacyjne Zofii Dobkowskiej, Warszawa.

5. Błażejewski W., 2006, Problemy rozwoju postaw przedsiębiorczych u gimnazjalistów [w:] Rola przedsiębiorczości w podnoszeniu konkurencyjności społeczeństwa i gospodarki, Z. Zioło, T. Rachwał (red.), Przedsiębiorczość - Edukacja nr 2, Warszawa-Kraków, s. 242-248.

6. Borowiec M., 2005, Rola praktyk z przedsiębiorczości w kształceniu studentów specjalności „geografia z przedsiębiorczościq" [w:] Przedsiębiorczość a współczesne wyzwania edukacyjne, Z. Zioło, T. Rachwał, Przedsiębiorczość - Edukacja nr 1, Kraków, s. 167-174.

7. Gabała J., 2005, Ksztattowanie postaw przedsiębiorczych uczniów [w:] Przedsiębiorczość a współczesne wyzwania edukacyjne, Z. Zioło, T. Rachwał (red.), Przedsiębiorczość - Edukacja nr 1, Kraków, s. $145-152$.

8. Górz B., Rachwał T., 2006, Uwagi do projektu zmian podstawy programowej podstaw przedsiębiorczości (zrealizowanej przez ISP na zlecenie MEN) [w:] Rola przedsiębiorczości w podnoszeniu konkurencyjności społeczeństwa i gospodarki, Z. Zioło, T. Rachwał (red.), Przedsiębiorczość -Edukacja $n r$ 2, Warszawa-Kraków, s. 226-235.

9. Historia. Wiedza o społeczeństwie. Podstawy przedsiębiorczości, 2008, Ministerstwo Edukacji Narodowej, Warszawa (materiały opisowe dotyczące projektu podstawy programowej, publikacja dostępna na www.men.gov.pl 15.10.2008 r.).

10. Juchnowicz M., 2005, Uwagi dotyczace realizacji przedmiotu podstawy przedsiębiorczości [w:] Przedsiębiorczość a wspótczesne wyzwania edukacyjne, Z. Zioło, T. Rachwał (red.), Przedsiębiorczość - Edukacja $n r$ 1, Kraków, s. 189-194. 
11. Kawecki Z., 2005, Ranga przedmiotu podstawy przedsiębiorczości w edukacji szkolnej [w:] Przedsiębiorczość a współczesne wyzwania edukacyjne, Z. Zioło, T. Rachwał (red.), Przedsiębiorczość - Edukacja nr 1, Kraków, s. 203-206.

12. Kilar W., 2007, Zagadnienia globalizacji i korporacji ponadnarodowych w edukacji przedsiębiorczości [w:] Rola przedsiębiorczości w aktywizacji gospodarczej, Z. Zioło, T. Rachwał (red.), Przedsiębiorczość - Edukacja nr 3, Warszawa-Kraków, s. 297-304.

13. Kompetencje kluczowe. Realizacja koncepcji na poziomie szkolnictwa obowiazkowego, 2005, Eurydice, Fundacja Rozwoju Systemu Edukacji, Warszawa.

14. Kosała M., Pichur A., 2008, Analiza działań przedsiębiorczych i postrzeganie prowadzenia działalności gospodarczej wśród mtodego pokolenia - wybrane aspekty [w:] Rola przedsiębiorczości w gospodarce opartej na wiedzy, Z. Zioło, T. Rachwał (red.), Przedsiębiorczość - Edukacja nr 4, Warszawa-Kraków, s. 347-353.

15. Kulikowska M. 2005, Możliwości wykorzystania komputera na zajęciach podstaw przedsiębiorczości na przykładzie lekcji nt. podatków pośrednich (scenariusz lekcji) [w:] Przedsiębiorczość a wspótczesne wyzwania edukacyjne, Z. Zioło, T. Rachwał (red.), Przedsiębiorczość - Edukacja nr 1, Kraków, s. 299-303.

16. Kulikowska M., Krasnodębska B., 2007, Techniki multimedialne w nauczaniu podstaw przedsiębiorczości [w:] Rola przedsiębiorczości w aktywizacji gospodarczej, Z. Zioło, T. Rachwał (red.), Przedsiębiorczość - Edukacja nr 3, Warszawa-Kraków, s. 308-316.

17. Łazowska E., 2005, Metodyka nauczania podstaw przedsiębiorczości i podstaw ekonomii [w:] Przedsiębiorczość a wspótczesne wyzwania edukacyjne, Z. Zioło, T. Rachwał (red.), Przedsiębiorczość - Edukacja $n r$ 1, Kraków, s. 251-254.

18. Maj T., 2003, Podstawy przedsiębiorczości. Poradnik dla nauczycieli liceów i techników: zakres podstawowy i rozszerzony, Oficyna Edukacyjna Krzysztof Pazdro, Warszawa.

19. Makieła B., 2006, Komunikacja interpersonalna w nauczaniu podstaw przedsiębiorczości [w:] Rola przedsiębiorczości w podnoszeniu konkurencyjności społeczeństwa i gospodarki, Z. Zioło, T. Rachwał (red.), Przedsiębiorczość - Edukacja nr 2, Warszawa-Kraków, s. 287-289.

20. Makieła Z., Makieła B., 2005, Nauczanie podstaw przedsiębiorczości w LO i LP [w:] Przedsiębiorczość a wspótczesne wyzwania edukacyjne, Z. Zioło, T. Rachwał (red.), Przedsiębiorczość - Edukacja $n r$ 1, Kraków, s. 177-188.

21. Makieła Z., Rachwał T., 2008, Podstawy przedsiębiorczości. Poradnik metodyczny, Nowa Era, Warszawa.

22. Mikina A., Sienna M., 2002, Przedsiębiorczość - klucz do sukcesu. Poradnik metodyczny dla nauczyciela. Podstawy przedsiębiorczości dla liceum ogólnoksztatcacego, liceum profilowanego i technikum, Rea, Warszawa.

23. Milewska M., 2006, Rozbudzanie postaw przedsiębiorczych wśród młodzieży wiejskiej [w:] Rola przedsiębiorczości w podnoszeniu konkurencyjności społeczeństwa i gospodarki, Z. Zioło, T. Rachwał (red.), Przedsiębiorczość - Edukacja nr 2, Warszawa-Kraków, s. 249-255.

24. Mitura E., Jamroz D., 2005, Przedsiębiorczy uczeń na rynku pracy [w:] Przedsiębiorczość a wspótczesne wyzwania edukacyjne, Z. Zioło, T. Rachwał (red.), Przedsiębiorczość - Edukacja $n r$ 1, Kraków, s. 297 i 298.

25. Mrożek J., 2008, „Dzień przedsiębiorczości” - szansą na lepsze przygotowanie uczniów szkót ponadgimnazjalnych do wejścia na rynek pracy [w:] Rola przedsiębiorczości w gospodarce opartej na wiedzy, Z. Zioło, T. Rachwał (red.), Przedsiębiorczość - Edukacja nr 4, Warszawa-Kraków, s. 355-359.

26. Musiałkiewicz, J., 2006, Podstawy przedsiębiorczości. Materiały dla nauczyciela w liceum ogólnokształcacym, liceum profilowanym $i$ technikum: podstawa programowa i program nauczania, korelacja międzyprzedmiotowa, plan wynikowy, ocenianie, testy, Ekonomik, Warszawa.

27. Nowak K., 2006, Problematyka globalizacji działalności sektora bankowego w edukacji szkolnej [w:] Rola przedsiębiorczości w podnoszeniu konkurencyjności spoteczeństwa i gospodarki, Z. Zioło, T. Rachwał (red.), Przedsiębiorczość - Edukacja nr 2, Warszawa-Kraków, s. 256-261.

28. Nowak K., 2008, Problematyka etyki biznesu w edukacji przedsiębiorczości [w:] Rola przedsiębiorczości $w$ gospodarce opartej na wiedzy, Z. Zioło, T. Rachwał (red.), Przedsiębiorczość - Edukacja nr 4, Warszawa-Kraków, s. 298-301. 
29. Osuch E., Osuch W., 2005, Przedmiot podstawy przedsiębiorczości w opinii uczniów i rodziców [w:] Przedsiębiorczość a współczesne wyzwania edukacyjne, Z. Zioło, T. Rachwał (red.), Przedsiębiorczość - Edukacja $n r$ 1, Kraków, s. 195-202.

30. Osuch E., Osuch W., 2007, Wybrane projekty edukacyjne w aktywizacji uczniów na lekcjach podstaw przedsiębiorczości [w:] Rola przedsiębiorczości w aktywizacji gospodarczej, Z. Zioło, T. Rachwał (red.), Przedsiębiorczość - Edukacja nr 3, Warszawa-Kraków, s. 305-307.

31. Piróg D., 2005, Miejsce i rola edukacji europejskiej $w$ nauczaniu podstaw przedsiębiorczości w kontekście wspótczesnych wyzwań cywilizacyjnych [w:] Przedsiębiorczość a wspótczesne wyzwania edukacyjne, Z. Zioło, T. Rachwał (red.), Przedsiębiorczość - Edukacja nr 1, Kraków, s. 213-220.

32. Podstawy przedsiębiorczości, 1995, J. Targalski (red.), Wydawnictwo Akademii Ekonomicznej, Kraków.

33. Podstawy przedsiębiorczości: analiza przypadków. Materiały pomocnicze do ćwiczeń, 1994, J. Targalski (red.), Wydawnictwo Akademii Ekonomicznej, Kraków.

34. Poradnik dyrektora szkoły. Jak organizować edukacje w gimnazjum i liceum?, 2008, Ministerstwo Edukacji Narodowej, Warszawa (publikacja dostępna na www.men.gov.pl 15.10.2008 r.).

35. Przedsiębiorczość a wspótczesne wyzwania cywilizacyjne, 2005, Z. Zioło, T. Rachwał (red.), Przedsiębiorczość - Edukacja nr 1, Wydawnictwo MiWa, Zakład Przedsiębiorczości i Gospodarki Przestrzennej IG Akademii Pedagogicznej w Krakowie, Kraków.

36. Przedsiębiorczość i zarządzanie. Studium przypadków, 2003, J. Targalski (red.), Wydawnictwo C.H.Beck, Warszawa.

37. Rachwał T., 2005b, Podstawy przedsiębiorczości. Słownik, Nowa Era, Warszawa.

38. Rachwał M., Rachwał T., 2005, Rola kształcenia umiejętności obstugi klienta na lekcjach podstaw przedsiębiorczości [w:] Przedsiębiorczość a współczesne wyzwania edukacyjne, Z. Zioło, T. Rachwał (red.), Przedsiębiorczość - Edukacja nr 1, Kraków, s. 221-226.

39. Rachwał T., 2005a, Ksztattowanie postaw uczniów na lekcjach przedsiębiorczości [w:] Przedsiębiorczość a współczesne wyzwania cywilizacyjne, Z. Zioło, T. Rachwał (red.), Przedsiębiorczość - Edukacja nr 1, Kraków, s. 137-144.

40. Rachwał T., Kudełko J., Tracz M., Wach K., Kilar W., 2008, Projekt podstawy programowej kształcenia ogólnego $w$ zakresie rozszerzonym dla liceum ogólnoksztatcacego, liceum profilowanego i technikum $z$ podstaw przedsiębiorczości [w:] Rola przedsiębiorczości w gospodarce opartej na wiedzy, Z. Zioło, T. Rachwał (red.), Przedsiębiorczość - Edukacja nr 4, Warszawa-Kraków, s. 312-324.

41. Rola przedsiębiorczości w aktywizacji gospodarczej, 2007, Z. Zioło, T. , Rachwał (red.), Przedsiębiorczość - Edukacja nr 3, Wydawnictwo Nowa Era, Zakład Przedsiębiorczości i Gospodarki Przestrzennej IG Akademii Pedagogicznej w Krakowie, Warszawa-Kraków.

42. Rola przedsiębiorczości w gospodarce opartej na wiedzy, 2008, Z. Zioło, T. Rachwał (red.), Przedsiębiorczość - Edukacja nr 4, Wydawnictwo Nowa Era, Zakład Przedsiębiorczości i Gospodarki Przestrzennej IG Uniwersytetu Pedagogicznego w Krakowie, Warszawa-Kraków

43. Rola przedsiębiorczości w podnoszeniu konkurencyjności spoleczeństwa i gospodarki, 2006, Z. Zioło, T. Rachwał (red.), Przedsiębiorczość - Edukacja nr 2, Wydawnictwo Nowa Era, Zakład Przedsiębiorczości i Gospodarki Przestrzennej IG Akademii Pedagogicznej w Krakowie, Warszawa-Kraków.

44. Soczówka M., 2007, Wykorzystanie technologii informacyjnej w nauczaniu-uczeniu się podstaw przedsiębiorczości [w:] Rola przedsiębiorczości w aktywizacji gospodarczej, Z. Zioło, T. Rachwał (red.), Przedsiębiorczość - Edukacja nr 3, Warszawa-Kraków, s. 317-324.

45. Sowislok K., 2008, Wiedza i umiejętności w nauczaniu przedsiębiorczości [w:] Rola przedsiębiorczości w gospodarce opartej na wiedzy, Z. Zioło, T. Rachwał (red.), Przedsiębiorczość - Edukacja nr 4, Warszawa-Kraków, s. 331-337.

46. Szczepańska M., 2005, Scenariusz lekcji „Ochrona konsumenta” [w:] Przedsiębiorczość a wspótczesne wyzwania edukacyjne, Z.Zioło, T.Rachwał (red.), Przedsiębiorczość - Edukacja nr 1, Kraków, s. 297 i 298.

47. Szmulczyńska B., 2006, Zapotrzebowanie środowiska szkolnego w zakresie edukacji ekonomicznej a oferta edukacyjna Portalu Edukacji Ekonomicznej Narodowego Banku Polskiego NBPortal.pl [w:] Rola przedsiębiorczości w podnoszeniu konkurencyjności społeczeństwa i gospodarki, Z. Zioło, T. Rachwał (red.), Przedsiębiorczość - Edukacja nr 2, Warszawa-Kraków, s. 279-286. 
48. Szubert M., 2008, Ksztaltowanie postaw przedsiębiorczych i promocja jakości pracy szkoty na przykładzie programu Certyfikat Jakości Szkoła Przedsiębiorczości [w:] Rola przedsiębiorczości w gospodarce opartej na wiedzy, Z. Zioło, T. Rachwał (red.), Przedsiębiorczość - Edukacja nr 4, Warszawa-Kraków, s. 360-367.

49. Śrutowska D., 2006, Wykorzystanie multimediów w nauczaniu przedsiębiorczości [w:] Rola przedsiębiorczości w podnoszeniu konkurencyjności społeczeństwa i gospodarki, Z. Zioło, T. Rachwał (red.), Przedsiębiorczość - Edukacja nr 2, Warszawa-Kraków, s. 264-278

50. Tracz M., 2005, O niektórych kryteriach doboru treści nauczania do podstawy programowej i programu nauczania z podstaw przedsiębiorczości [w:] Przedsiębiorczość a wspótczesne wyzwania edukacyjne, Z. Zioło, T. Rachwał (red.), Przedsiębiorczość - Edukacja nr 1, Kraków, s. 207-212.

51. Tracz M., 2006, Rola i znaczenie podstaw przedsiębiorczości w ksztatceniu ogólnym [w:] Rola przedsiębiorczości w podnoszeniu konkurencyjności społeczeństwa i gospodarki, Z. Zioło, T. Rachwał, Przedsiębiorczość - Edukacja nr 2, Warszawa-Kraków, s. 222-225.

52. Tracz M., Rachwał T., 2007, Przedmiot podstawy przedsiębiorczości - założenia realizacji a przygotowanie nauczycieli [w:] Rola przedsiębiorczości w aktywizacji gospodarczej, Z. Zioło, T. Rachwał (red.), Przedsiębiorczość - Edukacja nr 3, Warszawa-Kraków, s. 286-296.

53. Tracz M., Rachwał T., 2008, Metody $i$ środki dydaktyczne stosowane przez nauczycieli podstaw przedsiębiorczości - wyniki badań [w:] Rola przedsiębiorczości w gospodarce opartej na wiedzy, Z. Zioło, T. Rachwał (red.), Przedsiębiorczość - Edukacja nr 4, Warszawa-Kraków, s. 325-330.

54. Uzasadnienie. Projekt rozporzadzenia MEN w sprawie podstawy programowej wychowania przedszkolnego oraz kształcenia ogólnego w poszczególnych typach szkół, 2008, Ministerstwo Edukacji Narodowej, Warszawa (publikacja dostępna na www.men.gov.pl 15.10.2008 r.).

55. Wawrzyniak J., Szymczykiewicz W., Namysł E., 2006, Przedsiębiorczość w szkole i poza szkoła, Dom Wydawniczy ABC, Warszawa.

56. Zalecenie 2006/962/WE Parlamentu Europejskiego i Rady z dnia 18 grudnia 2006 r. w sprawie kompetencji kluczowych w procesie uczenia się przez całe życie (Dz.U. L 394 z 30.12.2006 r., str. 10).

57. Zioło Z., 2005a, Światowe uwarunkowania rozwoju przedsiębiorczości [w:] Przedsiębiorczość a współczesne wyzwania cywilizacyjne, Z. Zioło, T. Rachwał, Przedsiębiorczość - Edukacja nr 1, Kraków, s. 9-15.

58. Zioło Z., 2005, Kształcenie nauczycieli do nauczania przedsiębiorczości na specjalności „,geografia z przedsiębiorczościa [w:] Przedsiębiorczość a wspótczesne wyzwania cywilizacyjne, Z. Zioło, T. Rachwał (red.), Przedsiębiorczość - Edukacja nr 1, Kraków, s. 161-166.

59. Zioło Z., 2006, Rola przedsiębiorczości w podnoszeniu konkurencyjności społeczeństwa i gospodarki [w:] Rola przedsiębiorczości w podnoszeniu konkurencyjności spoteczeństwa i gospodarki, Z. Zioło, T. Rachwał (red.), Przedsiębiorczość - Edukacja nr 2, Warszawa-Kraków, s. 10-17

60. Zioło Z., 2007, Rola przedsiębiorczości w aktywizacji gospodarczej-zarys modelu [w:] Rola przedsiębiorczości w aktywizacji gospodarczej, Z. Zioło, T. Rachwał (red.), Przedsiębiorczość - Edukacja $n r$ 3, Warszawa-Kraków, s. 10-17. 